\title{
High and low latitude controls on Mid-Brunhes coccolithophore bloom and its implications on ocean carbon cycle
}

Hongrui Zhang

ETH Zurich https://orcid.org/0000-0003-1782-5976

Chuanlian Liu

Tongji University

Iván Hernández囚Almeida

ETH Zurich

Luz Maria Mejia

ETH Zurich https://orcid.org/0000-0001-6958-0531

Heather Stoll ( $\square$ heather.stoll@erdw.ethz.ch )

ETH Zürich https://orcid.org/0000-0002-2953-7835

\section{Article}

Keywords: Orbital Scale Variations, Deep Sea Dissolution, Global Rain Ratio, Ocean Carbonate System, Silicic Acid Leakage, Monsoon-related Nutrient Supply

Posted Date: March 16th, 2021

DOI: https://doi.org/10.21203/rs.3.rs-294199/v1

License: (c) (i) This work is licensed under a Creative Commons Attribution 4.0 International License. Read Full License 
1 High and low latitude controls on Mid-Brunhes coccolithophore bloom and its

2 implications on ocean carbon cycle

3 Hongrui Zhang ${ }^{1,2}$, Chuanlian Liu ${ }^{1 *}$, Iván Hernández-Almeida², Luz María Mejía², Heather M. Stoll²*

41 State Key Laboratory of Marine Geology, Tongji University, Siping Road 1239, Shanghai 200092,

5 China;

62 Department of Earth Sciences, ETH, Zurich, Sonnegstrasse 5, 8092 Zurich, Switzerland;

Correspondence and requests for materials should be addressed to C.L. (email: liucl@tongji.edu.cn) and H.M.S (email: heather.stoll@erdw.ethz.ch).

\section{Abstract}

Periodic $\sim 400$ kyr orbital scale variations in the ocean carbon cycle, manifest in indicators of deep sea dissolution and benthic ${ }^{13} \mathrm{C}$, have been observed throughout the Cenozoic ${ }^{1}$ but the driving mechanisms remain under debate. Changes in coccolithophore productivity may change the global rain ratio ( $\mathrm{C}_{\text {organic }}: \mathrm{C}_{\text {inorganic }}$ fluxes from ocean into sediment) and the balance of ocean carbonate system and thereby, potentially contributing to the $\sim 400$ kyr oscillation of the marine carbon cycle$^{2}$. Some evidence suggests that Pleistocene coccolithophore productivity was characterized by "bloom" events of high productivity coincident with the orbital benthic ${ }^{13} \mathrm{C}$ signal ${ }^{3}$. However, there is no consensus on the mechanism responsible for bloom events nor whether they were regional or global phenomena. In this study, we investigate the timing and spatial pattern of the most recent purported coccolithophore bloom event, which occurred during the Mid-Brunhes period. We find that maximum coccolithophore productivity is diachronous, peaking in the Southern Ocean sub-Antarctic zone with eccentricity minimum ( $\sim 30 \mathrm{ka}$ ), peaking in upwelling zones some $\sim 28 \mathrm{kyr}$ later, and finally peaking in the western tropical Pacific occurred some 80 kyr later. Simple globally homogeneous mechanisms of driving productivity such as temperature or light duration are not consistent with this pattern. Rather, we propose a dual high and low latitude control on blooms. Coincident with eccentricity minimum, increased high-latitude diatom silica consumption lowers the Si/P, leading to coccolithophorid blooms in the Southern Ocean north of the polar front. Coincident with increasing eccentricity, stronger tropical monsoons deliver higher fluvial nutrients to surface waters, increasing total (diatom and coccolithophore) productivity. Most of the tropical and subtropical locations are influenced by both processes with varying degrees, through the effect of silicic acid leakage on tropical thermocline waters 
33 and monsoon-related nutrient supply. Moreover, we propose that the high latitude processes have intensified over the Pleistocene, extending the 405 kyr carbon cycle to about $500 \mathrm{kyr}$. 35 


\section{Main text}

Primary productivity affects marine ecosystems and the efficiency of the biological carbon pump which in turn modulates the carbon cycle and climate. Siliceous and carbonate mineralizing eukaryotic phytoplankton, diatoms and coccolithophores, respectively, are hypothesized to be especially important to the carbon cycling because minerals effectively ballast and enhance deep export of carbon. Seafloor sediments record a pronounced acme in coccolithophore abundance around $400 \mathrm{ka}$, termed "bloom", which was dominated by the species Gephyrocapsa caribbeanica ${ }^{4}$. This coccolithophore bloom may not be a unique event but one in a series of coccolithophore evolutionary events since the early Pleistocene ${ }^{5}$. Previously proposed mechanisms for driving coccolithophore blooms at low eccentricity, by either maximizing annual light duration, or minimizing competition with diatoms due to Southern ocean Silicate leakage ${ }^{3}$, have been based on the inference of a synchronous global coccolithophorid bloom. However, even for the most recent purported coccolithophore bloom of the Mid-Brunhes, it is not clear whether the high coccolithophore abundance is dominantly due to increased productivity rather than to better sediment preservation, nor if there was a globally widespread and synchronous bloom event. Significantly, Pleistocene coccolithophore bloom events appear to coincide with cyclic variations in deep ocean ${ }^{13} \mathrm{C}^{3}$, global carbonate dissolution ${ }^{6}$, and benthic foraminifera extinction ${ }^{7}$, suggesting a link with the ocean carbon cycle. Ocean carbon cycle box models suggest that changes in productivity, in combination with variation in the rain ratio could explain the dissolution and benthic ${ }^{13} \mathrm{C} \mathrm{cycles}^{8}$, but have not evaluated what processes could drive changes in productivity or the rain ratio.

Here, we test whether the most recent bloom event reflects enhanced coccolithophorid production and if it was globally synchronous, using new 800 kyr coccolithophore productivity records from four ODP and IODP cores (Fig. 1, S1, S2), ODP 807 (West Pacific Warm Pool), ODP 1143 (West Pacific marginal sea), ODP 1170 (Southern Ocean) and IODP U1304 (North Atlantic), in which we evaluate independent evidence for coccolithophore growth rate and dissolution. We compare these with existing globally distributed coccolithophore $(n=14)$ and diatom productivity $(n=30)$ records (Fig. 1a, Table S1 and Table S2). For coccolithophores, productivity records include both the absolute abundance and accumulation rate of the main bloom forming Noelaerhabdaceae coccolithophore class (Noel. Ab. and Noel. AR, respectively), as well as the relative abundance of deep photic dweller Florisphaera profunda ( $\mathrm{Fp} \%)$, an indicator inversely related to primary productivity ${ }^{9}$. These proxies are highly correlated (Supplementary Fig. S1). Cross-correlation analyses between eccentricity and these coccolithophore productivity proxies are performed to detect the exact timing of coccolithophore bloom peaks (Methods and Supplementary S3). The carbon isotopic fractionation of coccoliths in core 
ODP 807 , sensitive to coccolithophore growth rate ${ }^{10}$, was analyzed to evaluate if dissolution affects the estimated timing of the bloom peak detected from coccolith abundance and assemblage data.

We find that the Mid-Brunhes coccolithophore bloom was not globally simultaneous but time transgressive from the Southern Ocean to the tropics. We propose that the interplay of high latitude processes (silica leakage) and low latitude processes (monsoon stimulation of weathering and fluvial nutrient supply and wind-driving water mixing) shaped the coccolithophore bloom pattern, and thereby marine carbon cycles, in the last $800 \mathrm{kyr}$. These results add a new global perspective on the coccolithophore bloom timing and pattern around the Mid-Brunhes Event and the interactions between calcareous and silicic productivity in the ocean. Moreover, our results will help to reveal the mechanism responsible for carbon cycle oscillations during the entire Pleistocene, which could be translatable to older time-scales.

\section{Results}

\section{Timing of coccolithophore bloom}

Previous studies suggested that the coccolithophore bloom event during the Mid-Brunhes was a global event lasting from $600 \mathrm{ka}$ to $300 \mathrm{ka}^{6}$ and has a close relation with low eccentricity ${ }^{3}$. The results of our cross-correlation analyses reveal that the coccolithophore bloom was strongly diachronous by tens of thousands of years across different regions (Figs 1, 2a). The bloom peaked first in the Southern Ocean around $470 \mathrm{ka}$, then in Equatorial Upwelling regions around $450 \mathrm{ka}$, and latest in the tropical Western Pacific and Indian oceans (after $400 \mathrm{ka}$ ). Overall, the lag between the peak in coccolithophore productivity and eccentricity minimum had a significant latitude preference $\left(R^{2}=0.57 p<<0.01\right.$, Figure 2b), with a slight lead to eccentricity minimum (ODP 1170) to in phase (ODP 1089) ${ }^{11}$ relationship in the Southern Ocean (Fig. 1e, Supplementary Fig. S5) , contrasting with lags of more than 60 kyr with the eccentricity minimum in most of the reconstructed productivity records in the tropical regions (Fig. 1c, Supplementary Fig. S5). In detail, a diversity of timings exists within the tropical ocean. The Eastern Pacific coccolith accumulation stack including sites ODP 1237, ODP 1238 and ODP $1240^{12,13}$ shows only about $28 \pm 1.5 \mathrm{kyr}$ lag to minimum eccentricity (Supplementary Fig. S5), while the coccolithophore bloom peaks in the West Pacific had a mean lag around $81 \pm 10$ kyr (Supplementary Fig. S5). Moreover, the low-eccentricity coccolithophore bloom was absent in the tropical Indian Ocean core, MD90-0963 ${ }^{9}$ (Supplementary Fig. S5). Weak correlations between coccolithophore productivity and eccentricity are seen in the northern hemisphere middle latitude such as the site IODP U1304 from the North Atlantic, the Portugal off-shore stack (MD01-2446 and IODP U1385 $5^{14,15}$ ) and site ODP $1209^{16}$ in the Northwestern Pacific (Supplementary Fig. S5), suggesting that the coccolithophore bloom was asymmetric between hemispheres. 

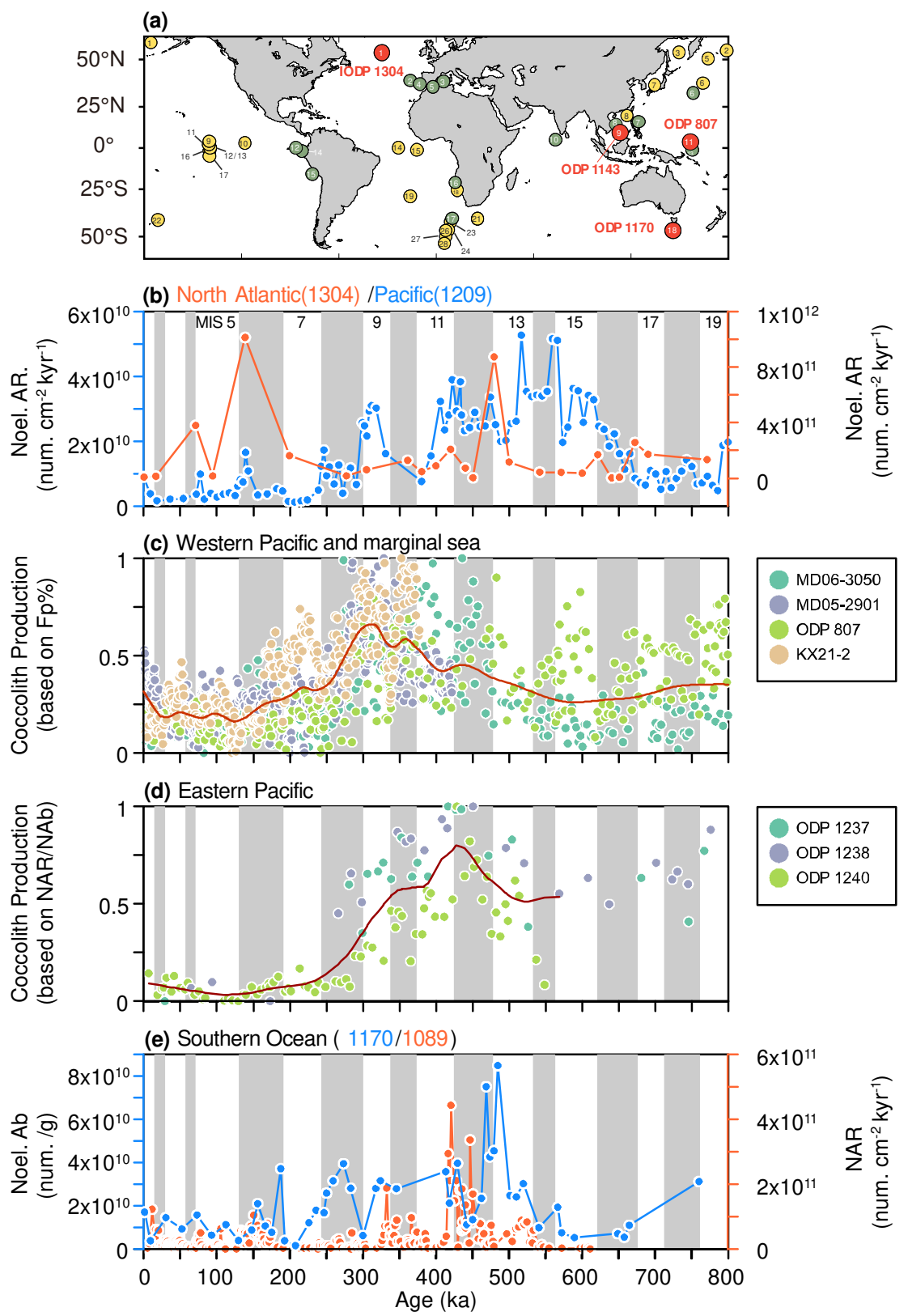

103 Figure 1 | Sites map and coccolithophore and diatom productivity in the last $\mathbf{0 . 8}$ Myr. (a) The sample map: the red dots are new coccolithophore productivity provided in this study, the green ones are published coccolithophore productivity and the yellow ones are diatom productivity cited in this work. The numbers of coccolithophore and diatom productivity records are in Supplementary Tables S1 and S2, respectively. (b) The coccolithophore productivity in the North Atlantic (orange, IODP U1304) and Pacific (blue, ODP 1209) ${ }^{16}$. (c) The normalized coccolithophore productivity stack (Fp\%) from the tropical West Pacific and marginal sea (dots) and the red curve is loess smooth of stack. (d) The normalized coccolithophore productivity stack in the Eastern Pacific upwelling (dots) and the red curve is loess smooth of productivity stack. (e) Coccolithophore productivity in the Southern Ocean (orange ODP 1089 and blue ODP 1170). 


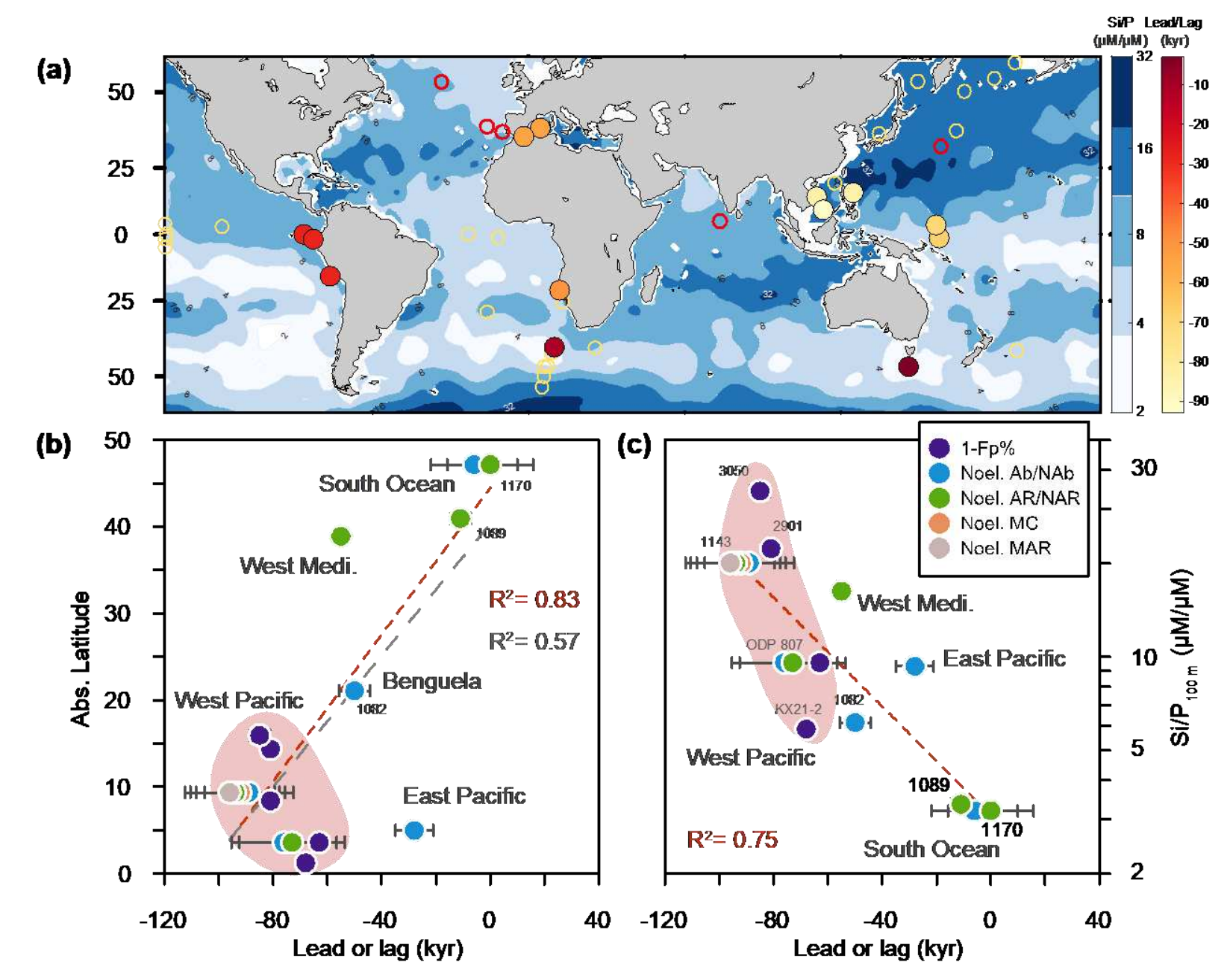

Figure2 | Coccolithophore bloom timing vs site location and nutrient ratio. (a) Coccolithophore bloom peak timing (relative to eccentricity minimum) against the core latitude and $\mathrm{Si} / \mathrm{P}$ ratio in the modern location of each core. Other diatom (yellow) or coccolithophore (red) productivity records cited in this work are plotted as circles. (b) The timing of coccolithophore bloom (relative to eccentricity minimum) against absolute latitude of cores. The red dash line represents the linear regression of data without Western Mediterranean and Eastern Pacific stacks $\left(R^{2}=0.83\right.$ and $p$-value $\left.<<0.001\right)$ and the gray dash line is the regression of all data $\left(R^{2}=0.57\right.$ and $p$-value $\left.<<0.001\right)$. A negative $x$-axis value represents the peak of coccolithophore productivity happened late than the eccentricity minimum. (c) Timing of coccolithophore bloom (relative to eccentricity minimum) against Si/P ratio in $100 \mathrm{~m}$ depth (from World Ocean Atlas ${ }^{17}$ ). The red dash line is the linear regression of the lead-lag result to nutrient ratio $\left(R^{2}=0.75\right.$ and $p$-value $\left.<<0.001\right)$. The shaded areas in $(b)$ and $(c)$ heighten results from Western Pacific.

\section{Potential effect of carbonate dissolution}

127 Paleoenvironmental information based on calcium carbonate shells produced by coccolithophores can 128 be biased due to dissolution ${ }^{18,19}$. The Mid-Brunhes period is characterized by a global carbonate 129 dissolution event ${ }^{6}$, which could have potentially shaped the leads and lags of coccolith-based proxies relative to eccentricity. Here we have two lines of evidence indicating that carbonate dissolution is not 
131 the major cause of the different timings of the coccolithophore productivity peaks recorded in 132 coccolith content and coccolith accumulation rate proxies. First, the Eastern Pacific stack included 133 three cores retrieved from different depths above the modern Carbonate Compensation Depth (CCD) , about $3600 \mathrm{~m}$ in the modern Eastern Pacific ${ }^{20}$ (Supplementary Table S1). In modern settings, coccolithophore productivity are similar among these three cores (Supplementary S7). We would expect the trends in coccolith accumulation in the deeper core to be most sensitive to dissolution. Although coccolith preservation changed with the dynamics of the CCD, coccoliths from the shallower core are better preserved than those from deeper cores, and coccolith abundances show in different order of magnitudes due to dissolution, the trends of coccolithophore productivity in these three cores agree closely from MIS 13 to MIS 11 (Fig. 1d). This suggests that temporal variations in dissolution have not generated the peak abundance nor exerted dominant influence of the timing on peak coccolith abundance in these sites.

143 In the Western Pacific, evidence that production, rather than dissolution, is dominantly controlling 144 coccolith productivity records is provided by the signal of growth rate in the coccolith carbon isotopic 145 fractionation. Carbon isotopic fractionation in coccoliths $\left(\Delta^{13} C_{\text {lith-DIC }}\right)$ is modeled to increase with higher coccolithophore growth rate, lower coccolithophore cell size and lower $\mathrm{CO}_{2 a q}$ concentration in the seawater ${ }^{10,21}$. The maximum in $\Delta^{13} C_{\text {lith-DIC }}$ and the coccolith productivity (from Noel. accumulation and F. profunda\%) occurred around $320 \mathrm{ka}$, while the cell sizes and $\mathrm{CO}_{2 \mathrm{aq}}$ were similar between the MIS 9 and MIS 11 (Supplementary Fig. S10), suggesting that maximum $\Delta^{13} C_{\text {lith-DIC }}$ at 320 ka likely reflects higher cell growth rate and coccolith production (Supplementary S4). Independent proxies from B/Ca ratio and foraminifer shell weight ${ }^{22,23}$ indicate stronger carbonate dissolution at $400 \mathrm{ka}$ (Fig. 3d), which

152 is a local minimum in Noel. abundance. However, the local minimum in $\Delta^{13} C_{\text {lith-DIC }}$ at 400 ka confirms 153 that Noel. abundance reflects lower coccolithophore growth and production, and is not an artefact of 154 stronger deep ocean dissolution. Consequently, the desynchronization of coccolithophore bloom in 155 the Western Pacific compared with Eastern Pacific and other high latitude sites is not an artefact of 156 preservation bias. 


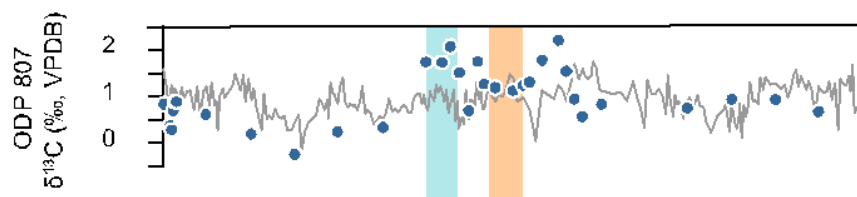

(b)

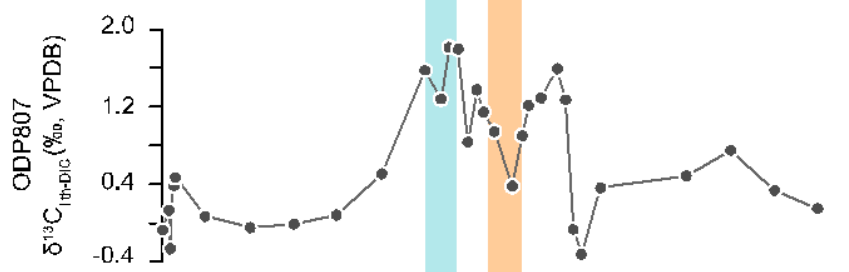

(c)

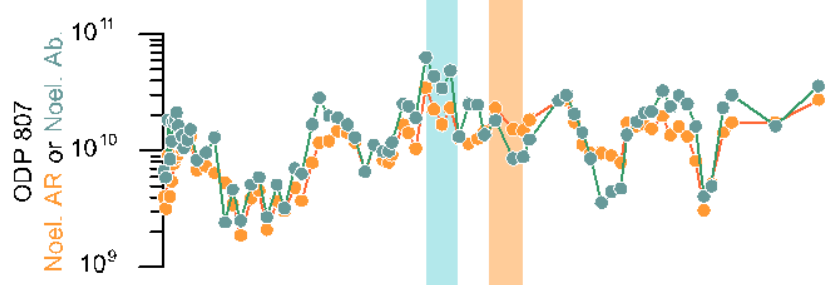

(d)

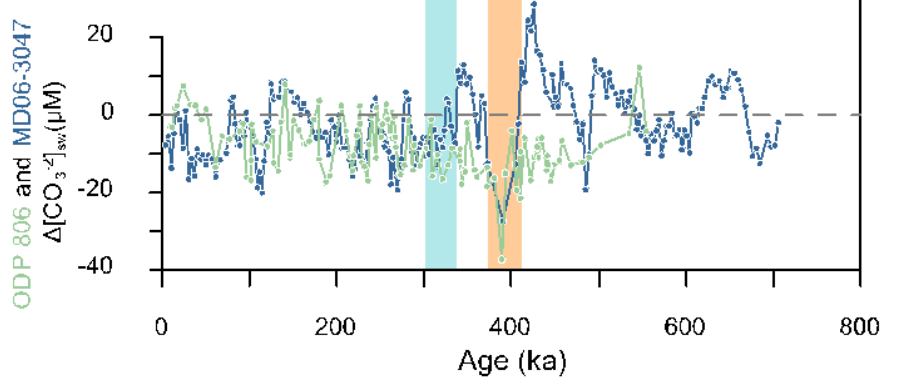

Figure 3 | Coccolithophore productivity and dissolution records from the Western Pacific: (a) Coccolith (blue dots) and foraminifera (grey line, G. ruber) ${ }^{24}$ carbon isotope in site ODP 807; (b) Calculated coccolith carbon isotope vital effect in site ODP 807, which is higher when the coccolithophores grow faster and the $\mathrm{CO}_{2 \mathrm{aq}}$ is lower assuming a fixed cellular PIC:POC ratio ${ }^{10}$. (c) Noelaerhabdaceae coccolith accumulation rate (Noel. AR, num. $\mathrm{cm}^{-2} \mathrm{kyr}^{-1}$ ) and abundance (Noel. Ab with a unit of num. $\left.\mathrm{g}^{-1}\right)$ in the core ODP 807; (d) $\Delta\left[\mathrm{CO}_{3}{ }^{2-}\right]$ reconstruction in the Western Pacific: green dots are based on benthic foraminifera B/Ca in site ODP $806^{22}$ and blue dots are based on G. ruber shell weight in the core of MD06-3047 ${ }^{23}$. The blue shading bar is the coccolithophore bloom peak detected in the Western Pacific and the orange one is the Mid-Brunhes dissolution event.

\section{Coccolithophore and diatom productivity pattern}

While diatoms also had significant peaks in productivity during the Mid-Brunhes periods, peak diatom productivity in most locations did not coincide with peak coccolithophorid productivity. Diatom blooms occurred in the absence of coccolithophorid blooms in the North Atlantic (IODP U1304, 53 $\mathrm{N}$ ), where there was no significant increase in Noelaerhabdaceae abundance or accumulation between $600 \mathrm{ka}$ and $300 \mathrm{ka}$. Yet, continuous diatom mats of Thalassiothrix longissima ${ }^{25}$ were found around $540 \mathrm{ka}^{26}$ (between MIS 14 and MIS 13, Fig. 4). In low latitudes, where both diatom and coccolithophores had elevated productivity in the Mid-Brunhes, the diatom bloom events were always out of phase with coccolithophore bloom events. In the South Atlantic north of modern polar front (ODP 1091, $47.09^{\circ} \mathrm{S}$ ), 
peak diatom bloom 570-540 ka ${ }^{27}$ (around MIS 15-14) preceded coccolithophore bloom in ODP 1070 $177\left(47.15^{\circ} \mathrm{S}\right)$ and ODP $1089\left(40.94^{\circ} \mathrm{S}\right)$. Only in the Southern Ocean sectors south of the modern polar front 178 (ODP 1093 and ODP 1094) was the enhanced biogenic opal export between 420-360 ka (around MIS $17911)^{28}$ synchronous with that of the coccolithophore bloom.

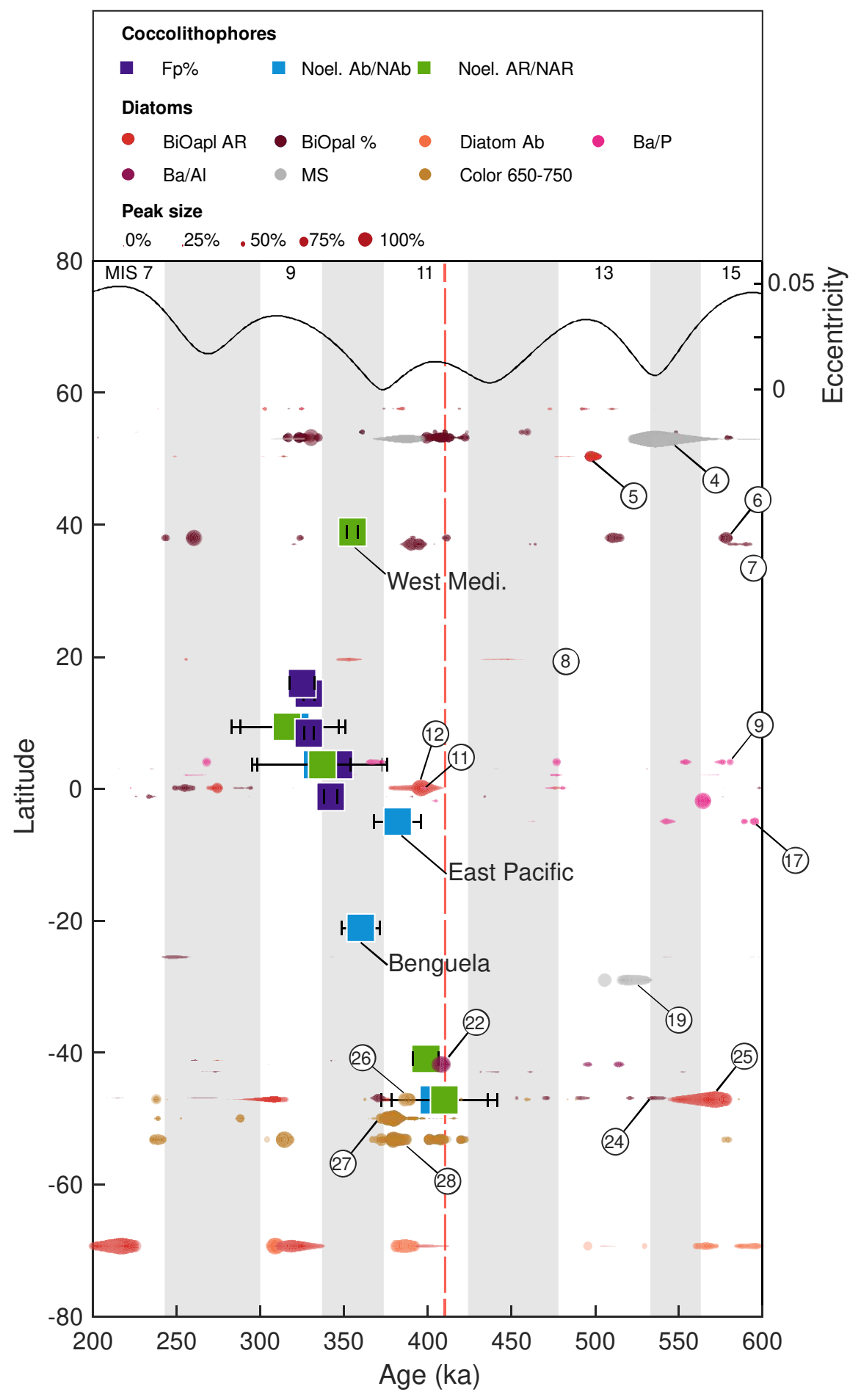

Figure 4 | The bloom pattern of coccolithophore and diatom from $600 \mathrm{ka}$ to $200 \mathrm{ka}$. The squares are the timing of coccolithophore bloom peaks and the different colors represent bloom peaks recorded by different proxies (see the legend). The numbers are diatom productivity records listed in 
Supplementary Table S2. The red dashed line represents the eccentricity minimum on the $405 \mathrm{kyr}^{-1}$ band. The error bars are 95\% confidence interval of coccolithophore bloom peak timing estimation base on cross-correlation. The dots are diatom high productivity periods and different colors represent results from each proxy (see the legend). Diatom productivity peaks represent periods when the productivity was larger than mean value+2 standard deviation in a $200 \mathrm{kyr}$ window (Method and Supplementary S3). A larger size of dots represents a more significant diatom productivity peak: $0 \%$ represents the smallest peak and $100 \%$ represent the largest productivity peak in the last $0.8 \mathrm{Myr}$. The results of Noel. MC and Noel. MAR from the core ODP 1143 are covered by Noel. Ab and Noel. AR squares and do not appear in the figure legend.

\section{Nutrient $\mathrm{Si} / \mathrm{P}$ ratio as a driver of diachronous bloom}

The significant differences in the timing of peak bloom conditions across the ocean suggests that globally varying factors such as sea surface temperature or growth season light were not likely to be the dominant drivers of the mid-Brunhes coccolithophore bloom. Maximum temperatures were reached at all latitudes in the MIS 11 interglacial, so a diachronous coccolithophore bloom cannot result from direct influence of temperature. Likewise, at the eccentricity band, the growing season length defined by light intensity varies coherently between the north and south hemisphere. Alternatively, redistribution of nutrients in the surface ocean may be a possible cause of spatially variable bloom timing. We find weak correlations between the bloom timing and the modern silica and phosphate concentration in modern ocean at 100-meter depth (Supplementary Fig. S12). However, the spatial lag in Mid-Brunhes coccolithophore bloom timing compared to the eccentricity minimum is inversely correlated with the spatial variations in Si/P ratio which characterize the modern ocean $\left(R^{2}\right.$ $=0.750<<0.01$, Fig. 2c). A similar significant correlation is also found between bloom timing and the $\mathrm{Si} / \mathrm{N}$ ratio (Supplementary Fig. S12). The region currently characterized by low Si/P, such as the Southern Ocean and the Eastern Pacific upwelling zone, are those which experienced the earliest coccolithophorid bloom events and the Mid-Brunhes period (MIS 13-12). In contrast, regions currently characterized by high Si/P had later coccolithophorid bloom peaks (MIS 11-9; Fig. 2c).

\section{Discussion}

Our records of coccolithophore productivity within the Mid-Brunhes period enabled us to identify three key diagnostic features of coccolithophore bloom during the minimum eccentricity. First, there is globally widespread evidence for elevated coccolithophore productivity during the low eccentricity Mid-Brunhes interval but peak productivity is diachronous with lags up to $80 \mathrm{kyr}$. Second, the varying timing of peak coccolithophore bloom from high to low latitude regions correlates with the modern nutrient ratio (Si/P). Third, peak coccolithophore and diatom bloom are diachronous except in the 
Southern Ocean. These findings provide new clues to reveal the mechanisms controlling coccolithophore blooms and implications in the marine carbon cycle.

A secular cyclicity of coccolithophore productivity has been described in previous studies ${ }^{3}$. The MidBrunhes coccolithophore bloom event is one of the acmes during the Pleistocene, followed by the $E$. huxleyi acmes from 170 ka to the present, and preceded by acmes of small Gephyrocapsa around the $800 \mathrm{ka}, 1100 \mathrm{ka}$ and $1700 \mathrm{ka} \mathrm{a}^{4,5,7}$. Previous explanations of coccolithophore blooms include an extended growth season during low eccentricity periods, less silicic acid leakage from the Southern Ocean and weathering enhanced by terrestrial biosphere ${ }^{3}$. The changes of growth duration were small (more details in the Supplementary S6) and a mechanism for amplifying these variations into more than one order of magnitude variations in coccolith abundance and accumulation rate, as recorded in sediment, has not yet been described. Moreover, the growth season length follows the pace not only of eccentricity, but of precession as well. So, the longest growth season appeared at the precession peak during eccentricity maximum around 200 ka (Fig. 5a and Supplementary Fig. S13) rather than during the eccentricity minimum when coccolithophores bloomed.

Several factors could have contributed to high diatom and coccolithophore productivity in the subAntarctic sector of the Southern Ocean during the MIS 13-11 eccentricity minimum, including the enhanced dust input ${ }^{29-31}$, the melting and retreat of Antarctic ice-sheet ${ }^{32}$, and thereby, the poleward migration of polar front ${ }^{28}$. At the same time, the utilization of silicic acid by diatoms in the Southern Ocean is proposed to control the type of tropical productivity and total productivity in the ocean ${ }^{33}$. Because the Southern Ocean is the source of sub-Antarctic mode water which upwells in the tropical thermocline ${ }^{34}$, increased diatom production and silicic acid drawdown in the Southern Ocean would lead to upwelling of water rich in phosphate but deficient in silica in the low latitudes. This process could depress the success of diatoms and favor non-silicifying phytoplankton such as coccolithophores in the tropical and subtropical oceans, potentially contributing to low latitude coccolithophore bloom events. Indeed, in the modern ocean the highest concentration of coccolithophores in the surface ocean is found the region of low Si/P between 45 and $40 \mathrm{~S}^{35}$.

While this process is consistent with a coccolithophore, but not diatom bloom in the Eastern Pacific upwelling zones, with a small ( $20 \mathrm{kyr}$ ) lag relative to Southern Ocean diatom production (a detailed explanation for Eastern Pacific lag in Supplementary S7), it is not consistent with the very long ( 60-80 kyr) lag of coccolithophore bloom peaks in the Western Pacific Warm Pool and marginal seas compared to much shorter ocean circulation timescales. This longer lag suggests that dust deposition, dynamic of ice sheet and silica leakage are not the only mechanisms shaping the global coccolithophore bloom pattern. Instead, we propose that variation in an additional nutrient source, the monsoon and weathering in the low latitudes, is responsible for this lag among coccolithophore bloom events in 
252 different regions. The monsoon region is a weathering engine, with both rapid physical weathering

253 from fast uplift and rapid chemical weathering from high precipitation and plays important roles in the 254 global nutrient and carbon cycles ${ }^{36}$. The monsoon intensity was gradually enhanced from the minimum 255 eccentricity around 400 ka to maximum eccentricity around $200 \mathrm{ka}^{37}$ (Fig. 5f), causing a stronger wind256 driving mixing, more intense chemical weathering and delivering more nutrient, especially phosphate, 257 into ocean (Fig 5g). Therebefore, we suggest that monsoon-controlled processes provided another 258 important nutrient source fueling low latitude coccolithophore bloom, in the Western Pacific Warm 259 Poll and marginal seas, in addition to the suppression of diatoms from Southern Ocean silica 260 consumption effectively liberating more thermocline $\mathrm{P}$ and $\mathrm{N}$ for coccolithophores. Consequently, the 261 combination of two major nutrient sources, monsoon and high latitude processes, caused the 262 coccolithophore bloom peaks in the Western Pacific to lag the minimum eccentricity 60-80 kyr. In addition to the Western Pacific records (Fig. 6 b,e), the Eastern Mediterranean Stack of coccolithophore productivity also show a significant lag to the eccentricity minimum (Fig. 2). We suggest that the similarity in response of Mediterranean coccolithophore productivity with the tropical Western Pacific reflects the impact from the African monsoon on weathering and local nutrient level. For the region where the nutrient availability is dominated by monsoon processes, including both wind-driving upwelling and precipitation-controlled weathering, the maximum coccolithophore productivity should appear during maximum eccentricity when the monsoon intensity is stronger. This pattern has been discovered in the Tropical Indian Ocean coccolithophore records ${ }^{9}$. 
(a)

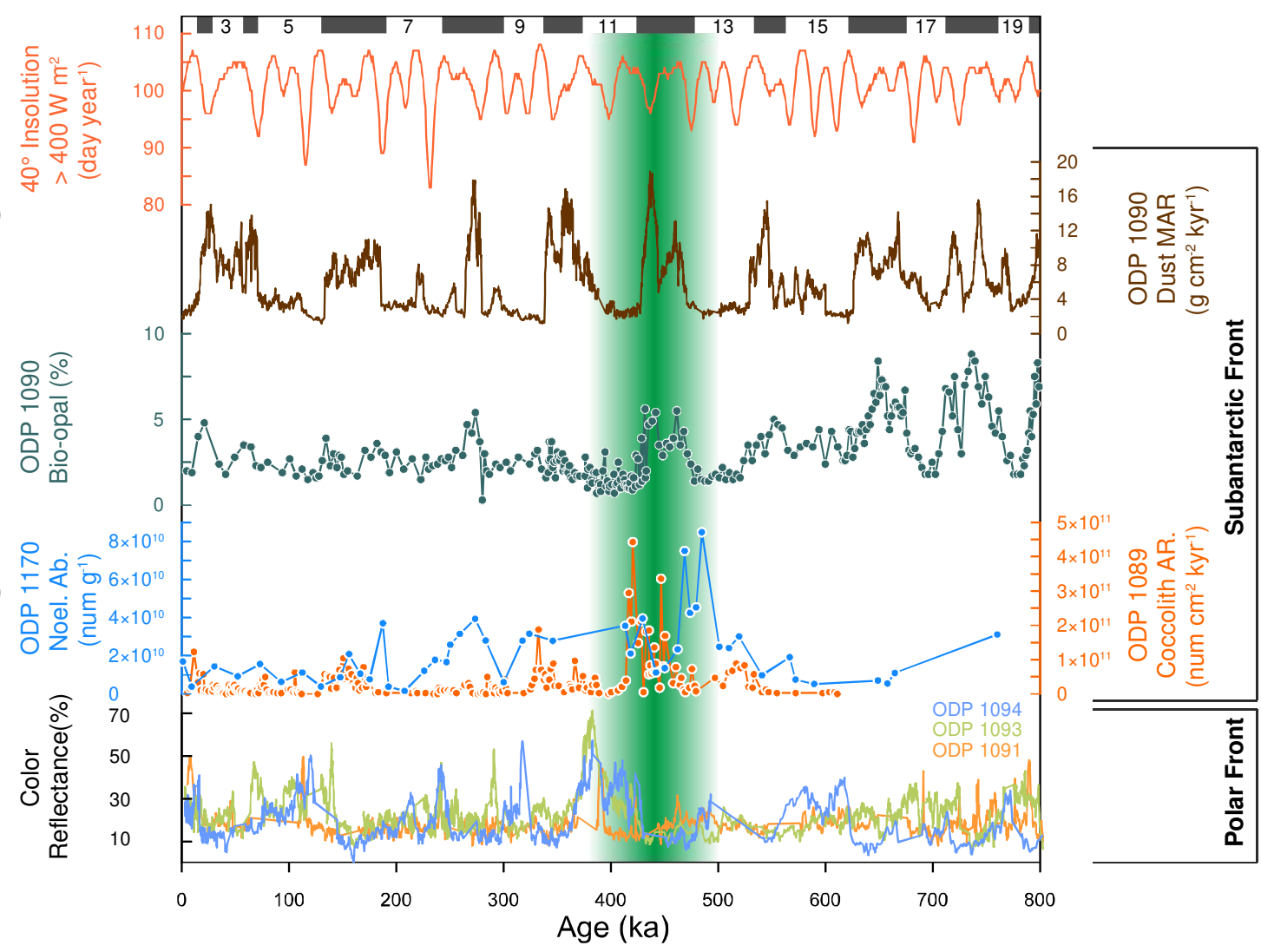

(f)

(f)
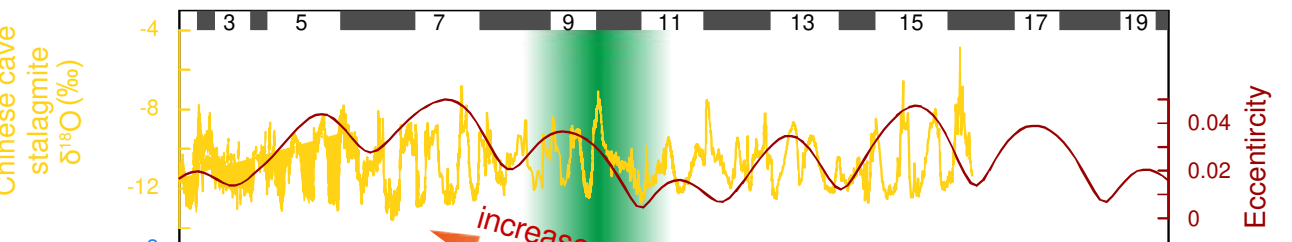

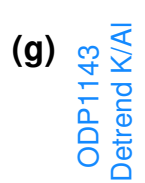

(h)

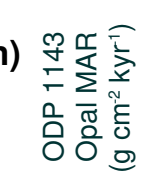

(i)
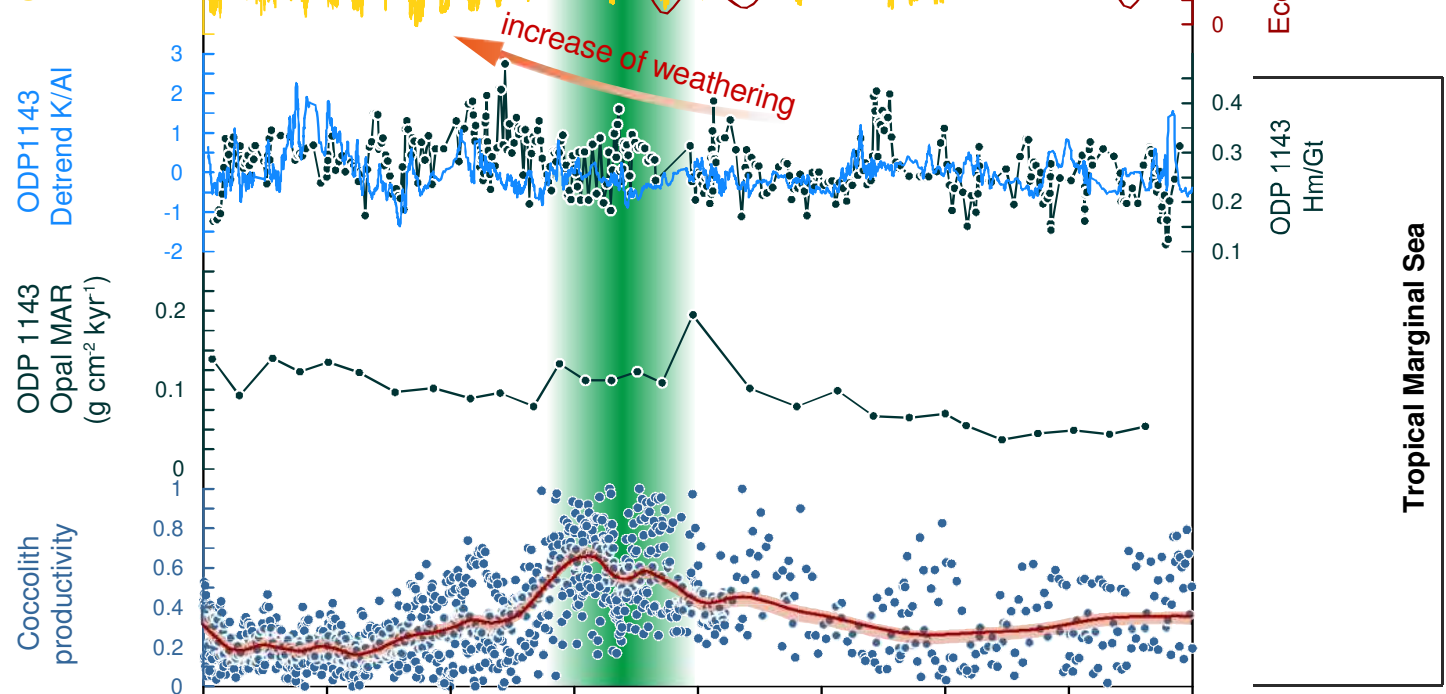

Figure 5 | Trigger mechanisms of coccolithophore blooms in tropical seas and mid-high latitude

ocean. The vertical green bars are coccolithophore bloom timing in the Southern Ocean (upper panel) and tropical West Pacific marginal seas (lower panel). (a) The coccolithophore growth season length defined a threshold of daily insolation $400 \mathrm{~W} \mathrm{~m}^{-2}$ (growth durations defined by other thresholds are shown in Supplementary Fig. S13). (b) Dust accumulation rate in the site ODP 1090 Southern Ocean ${ }^{29}$. 
(c) Biogenic opal mass accumulation rate (MAR) as an indicator of diatom productivity from the core

278 ODP $1090^{27}$. (d) Coccolithophore productivity from the core ODP 1170 (blue) and the core 1089 (orange). (e) Color reflectance of sites ODP 1091, 1093 and 1094 on the Polar Front ${ }^{28}$. (f) Oxygen isotope of Chinese caves stalagmite (yellow) is an indicator of the Asian summer monsoon which is enveloped by eccentricity parameter (red) on $100 \mathrm{kyr}$ and $405 \mathrm{kyr} \mathrm{band}^{37}$. (g) The weathering proxies from the core ODP 1143 in the South China Sea ${ }^{38}$. The blue curve is the K/Al ratio and the dark green dots are the Hematite/Goethite ratio which are indicator of precipitation on the Indochina Peninsula ${ }^{39}$. Both of these records show a rapid increase of summer monsoon and fluvial flux from MIS 10 to MIS 9. (h) The opal MAR as a proxy for diatom productivity for ODP $1143^{40}$. (i) The normalized coccolithophore productivity recorded by Fp\% in the Western Pacific (more details in the caption of Fig. 1c)

We propose that the Mid-Brunhes coccolithophore bloom event can be divided into three stages reflecting three different modes. In the first stage, the coccolithophore bloom occurred in the Sothern Ocean, triggered by dust input and southward polar front migration around MIS 13 consuming the silica. After the silica concentration in the Southern Ocean decreased, the Si/P ratio in the Southern Ocean decrease and coccolithophore began to bloom resulting diatom-nannofossil ooze in the SubAntarctic sediment. Later when the low Si/P water leaked out to the tropical ocean and coccolithophore began to bloom in the Eastern Pacific upwelling region around MIS 12 (Figs 5a and 6a). In the second stage, the gradually enhanced low latitude weathering and rainfall extended the coccolithophore bloom peaks from MIS 11 to MIS 9 in the monsoon-influenced regions (Fig. 5b). In the last stage, coccolithophore productivity reached maximum levels around MIS 8-7 where monsoon dominates the nutrient regime (Fig. 6c). We suggest that these three bloom stages reflect the contrasting relative balance of high and low latitude modulation of nutrient supply to the photic zone, and out of phase forcing of these processes in high and low latitudes in the long eccentricity band.

Higher benthic foraminiferal $\delta^{13} \mathrm{C}$ during $400 \mathrm{kyr}$ cycle minima in eccentricity have been interpreted as evidence of modulation of the global carbon cycle ${ }^{41}$. Previous models have shown that the $400-500 \mathrm{kyr}$ cycles in benthic $\delta^{13} \mathrm{C}$, and a concomitant cycle of $15 \mathrm{ppm}$ in $\mathrm{pCO}_{2}$, could be caused globally synchronous changes in the production ratio $\left(\mathrm{C}_{\text {inorg }} / \mathrm{C}_{\mathrm{org}}\right)$ in the surface ocean, implicating a shift in the balance of coccolithophorid production relative to that of non-calcifying phytoplankton ${ }^{8}$. In these simulations, the productivity ratio was varied simultaneously in the whole surface ocean in phase with long eccentricity forcing. Our results show that the production ratio changed because of the different bloom timings of coccolithophore and diatom. However, in contrast to a global synchronous variation, the variations in tropical region was significantly lagged from eccentricity, and coupled to changes in tropical monsoon. This new dataset provides a more precise phasing and location of changes in the 
changes in the production ratio and weathering, including changes in the ocean's alkalinity and oxygen balance ${ }^{42}$.

Since ice core measurements of $p \mathrm{CO}_{2}$ are limited to the last $800 \mathrm{kyr}$, it is difficult to directly evaluate the extent to which changes in coccolithophore production may also lead to long eccentricity cycles on atmospheric $\mathrm{CO}_{2}$. Low pass filtering of the ice core record has suggested a $20 \mathrm{ppm}$ amplitude of $p \mathrm{CO}_{2}$ at $400 \mathrm{kyr}$ band ${ }^{8}$. Similarly, a minimum in the phase lag between Antarctic temperature and obliquity, and ice volume and obliquity, between 450-350 ka has also been attributed to a $400 \mathrm{kyr}$ forcing of $\mathrm{CO}_{2}{ }^{43}$. More intense coccolithophore production in the Sub-Antarctic zone of the Southern Ocean, has been modeled to decrease the buffering capacity of the surface ocean globally and therefore reduce the $\mathrm{CO}_{2}$ uptake capacity of the ocean ${ }^{44}$. Therefore, the strong enhancement of coccolithophore production in the Sub-Antarctic zone which we show between 500-400 ka, should be investigated as a potential additional mechanism for modulation of atmospheric $\mathrm{CO}_{2}$ on long eccentricity periods.

Previous studies have proved that the long eccentricity cycles, including the $400 \mathrm{kyr}, 1.2 \mathrm{Myr}$ and 2.4 Myr cycles, were relative stable in the earth history, being detected in the sediment records from the Paleozoic to the Cenozoic ${ }^{45,46}$. However, the $400 \mathrm{kyr}$ power in benthic $\delta^{13} \mathrm{C}$ gradually weakened after $13 \mathrm{Ma}^{47}$, coincident with the expansion of the Antarctic ice sheet. During the Pleistocene, the period in benthic $\delta^{13} \mathrm{C}$ lengthened to a $~ 500 \mathrm{kyr}$ cycle after $1.8 \mathrm{Ma}^{48}$. These suggest that the evolving ice sheet and/or other high latitude processes modulated the response of the carbon cycle to long eccentricity forcing. We suggest that prior to the intensification of polar glaciation, the coccolithophorid and diatom bloom pattern, and thereby, production ratio in the ocean, may have responded mainly to the intensity of monsoon, through weathering and nutrient delivery by river $^{1}$ or wind-driven upwelling, with a cycle of $\sim 400 \mathrm{kyr}$. However, intensified polar glaciation may have significantly increased the amplitude of 400 kyr variation in high latitude processes which could affect the nutrient pattern and $\mathrm{Si} / \mathrm{P}$ ratio of the ocean, via such as sea ice extent, deep water formation, or silicic acid leakage. Consequently, the $400 \mathrm{kyr}$ monsoon-controlled nutrient addition at high eccentricity during the prepolar glaciate world would have been partly overprinted by a high latitude-driven increase in low latitude thermocline Si/P at low eccentricity, leading first to a weakening of the $400 \mathrm{kyr}$ power. The reemergence of power at $500 \mathrm{kyr}$ band in the last $1.8 \mathrm{Myr}$ may reflect a rebalancing of the relative amplitude of these two processes, attesting to a change in the carbon cycle. 
(a) MIS 13-MIS 11

Peak of Mid-Brunhes bloom at high latitude and upwelling

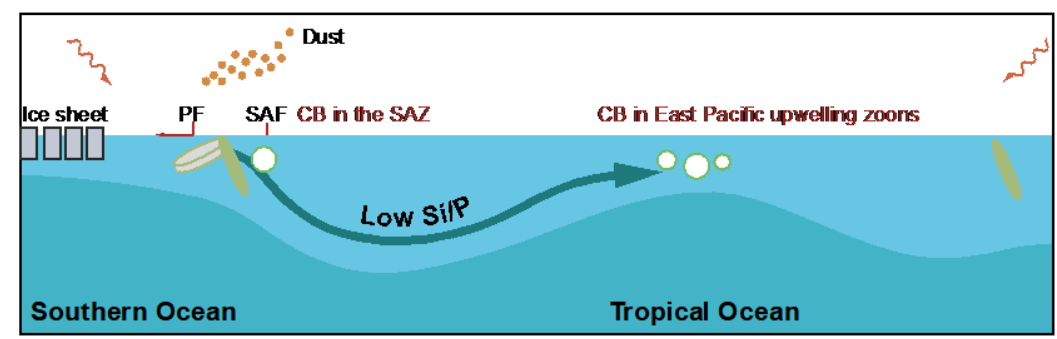

(b) MIS 11-MIS 9

Peak of Mid-Brunhes bloom at the Westem Pacific

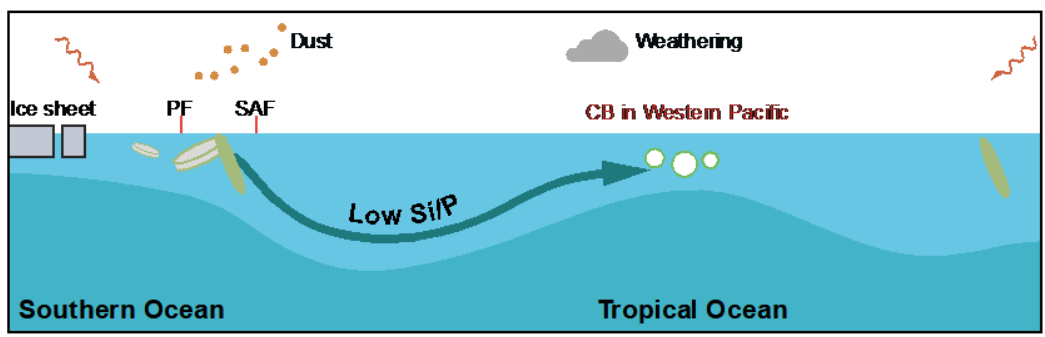

(c) MIS 9-MIS 7

High coccolithophore productivity period in the monsoon-driven upwelling zoon

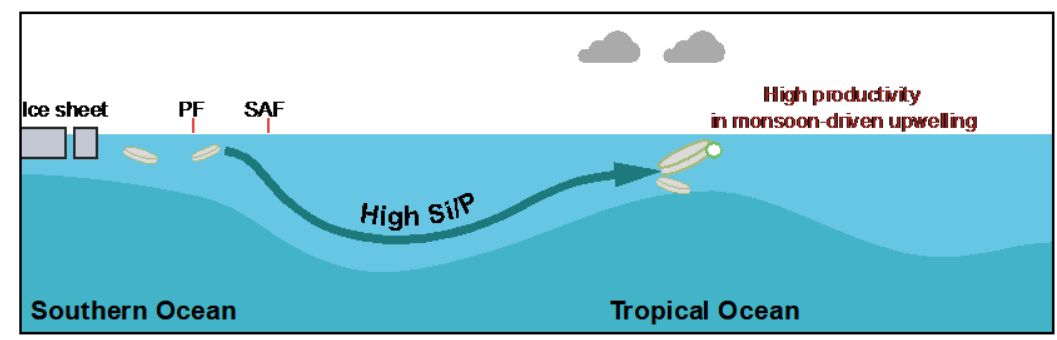
Front and $C B$ is coccolithophore bloom.
South Ocean Mode Peaks at MIS 13-MIS 11

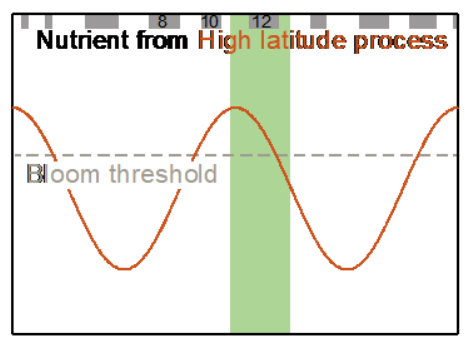

Western Pacific Mode

Peaks at MIS 11-MIS 9

(e)

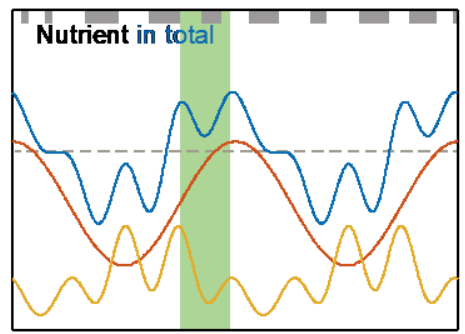

Tropical Indian Ocean Mode Peaks at MIS 9-MIS 7

(f)

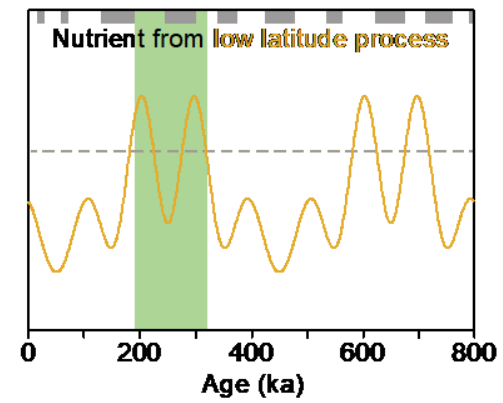

Figure 6 | Three modes of coccolithophore bloom around Mid-Brunhes and afterwards. Trigger processes of coccolithophore bloom in three time slices: (a) Coccolithophore bloom pattern in the Southern Ocean and Eastern Pacific during MIS 13-12. (b) Coccolithophore bloom pattern in the Western Pacific during MIS 11-9. (c) Coccolithophore high productivity in monsoon driven upwelling region during MIS 8-7. (d-f) Nutrient source fueling coccolithophore productivity in three bloom modes. The nutrient sources from high latitude and low latitude processes were assumed to be driven only by orbital parameters (more details Supplementary S7). PF is the Polar Front, SAF is the Sub-Antarctic 


\section{Methods}

\section{Samples and data selections}

In this study, we selected four ODP or IODP cores with oxygen isotope chronostratigraphy, for which we produced new coccolithophore productivity data. Other 14 cores with published coccolithophore productivity records longer than $300 \mathrm{kyr}$ or at least covering the Mid-Brunhes period were also reviewed in our research. The details of cores and proxies information can be found in Supplementary Table S1. We focus on the Noelaerhabdaceae family in our study and the coccolith-based productivity proxies, such as coccolith abundance and coccolith accumulation rate, are referred to the Noelaerhabdaceae abundance (Noel. Ab) and accumulation rate (Noel. AR) without specific statements. Beside the abundance and accumulation rate based on fossil numbers, we also measure the coccolith mass content (Noel. MC) and accumulation rate (Noel. MAR) in the core ODP 1143. Among the geochemistry proxies, we selected the coccolith carbon isotope fractionation $\left({ }^{13} C_{\text {lith-DIC }}\right)$ as a proxy for growth rate. The differences among selected coccolithophore productivity proxies are summarized in Table 1. The G. caribbeanica percentage was not treated as a proxy for determining the bloom timing in this study because we found in some sites such as IODP U1304 and ODP 1209, the G. caribbeanica\% seems to have low correlation with coccolith accumulation rate (Supplementary Figure S1d). We review 30 diatom-related productivity records in this study, including the biogenic opal content (BiOpal\%), biogenic opal accumulation rate (BiOpal AR), diatom absolute number in the sediment (diatom/g), $\mathrm{Ba} / \mathrm{Al}, \mathrm{Ba} / \mathrm{P}$, color reflectance and the magnetic susceptibility of the bulk sediment (more details in Supplementary S1, S2).

Table 1. Comparison among coccolithophore productivity proxies.

\begin{tabular}{|c|l|}
\hline Coccolith-based proxy & \multicolumn{1}{|c|}{ Potential bias } \\
\hline $1-\mathrm{Fp} \%$ & $\begin{array}{l}\text { Can't be employed as a productivity proxy beyond } \\
\text { tropical/subtropical ocean }\end{array}$ \\
\hline Noel. Ab / Noel. AR & Sensitive to dissolution \\
\hline Noel. MC /Noel. MAR & $\begin{array}{l}\text { More accurate on estimating coccolith's contribution to } \\
\text { carbonate. Consume more time to measure and could be sensitive } \\
\text { to dissolution. }\end{array}$ \\
\hline$\Delta^{13} C_{\text {lith-DIC }}$ & $\begin{array}{l}\text { A potential proxy for growth rate but needs isotopic model for a } \\
\text { better explanation. In some cases, the new productivity does not } \\
\text { covary with growth rate. }\end{array}$ \\
\hline
\end{tabular}

\section{Coccolith analyses}

Sliders for coccolith counting were prepared following the dropping technique ${ }^{49}$. At least 200 coccolith and 10 fields of view were counted for the coccolith abundance and accumulation rate analyses. The coccolith mass was estimated on the circular polarized microscope with the gray-level method 
following the method ${ }^{50,51}$, in which the intensity of light was calibrated via a well measured calcite wedge. About 40 pictures were taken from the same slider made for coccolith counting. Then import the pictures into Matlab, turn them from colorful pictures to gray picture and measure the gray level of each coccolith. The coccolith thickness was calculated by the brightness-thickness calibration. The coccolith surface area was achieved by turning the area of pix into square micron.

$$
\mathrm{m}_{c}=\sum(A \times T) \times 2.7
$$

where the $m_{c}$ means the mass of a single coccolith; the A means the area $\left(\mu \mathrm{m}^{2}\right)$ of a single pixel and the T represents the thickness of this pixel; 2.7 is the density of calcite carbonate with a unit of $\mathrm{g} \mathrm{cm}^{-3}$. It should be noted that the units for coccolith $A$ and $T$ are usually square micron and micron, so they should be turned into centimeter and square centimeter for the subsequent abundance and accumulation rate calculation.

$$
\mathrm{M}_{c}=\frac{\sum \mathrm{m}_{c}}{n} \times A b_{c}
$$

where $\mathrm{M}_{c}$ is the coccolith mass in the bulk sediment with a unit of $\mathrm{g}$ per $\mathrm{g}$ bulk sediment; the $\mathrm{n}$ is how many coccoliths were measured for a certain sample; $\frac{\sum \mathrm{m}_{c}}{n}$ is the average coccolith mass in all measurements. $A b_{c}$ is the abundance number of coccolith per gram bulk sediment. The coccolith mass accumulation rate was calculated by the following equation:

$$
C_{\mathrm{MAR}}=\mathrm{M}_{c} \times \rho_{\text {sed. }} \times \mathrm{LSR}
$$

Where the $\rho_{\text {sed. }}$ is the dry bulk density of sediment with a unit of $\mathrm{g} \mathrm{cm}^{-3}$ and the LSR is the linear sedimentation rate with a unit of $\mathrm{cm} \mathrm{kyr}^{-1}$.

In this study, coccoliths were separated by the centrifuging method ${ }^{52}$. This method shares the same principle with the settling method ${ }^{53,54}$. Before the separation, we soak about 40 mg bulk sediment into $10 \mathrm{ml} 2 \%$ ammonia solution overnight for disaggregation. Then the first step is separating the $F$. profunda, coccolith fragments and clay from bulk sediments using the angular velocity $1850 \mathrm{rpm}$ and duration $2 \mathrm{~min}$. To fully separate particles smaller than $2 \mu \mathrm{m}$, this step should be repeated for at least 8 times. The second step is separating the Gephyrospharea spp. from larger coccoliths using the angular velocity of $2500 \mathrm{rpm}$ and a duration of $1 \mathrm{~min}$. Most of Gephyrocapsa spp. within 2.5-4.5 $\mu \mathrm{m}$ are in the suspension pumped out in this step. The second step was repeated for 4-6 times. Then we filter the suspension on $0.2 \mu \mathrm{m}$ membrane and harvest coccoliths on the membrane. After separation, the coccolith carbon isotope were measured using a MAT 253 in ETH Zurich. DIC carbon isotope is necessary for coccolith carbon isotope vital effect, which was calculated as following:

$$
\delta^{13} C_{D I C}=\delta^{13} C_{G . r u b e r}+0.94 \% 0-1 \% 0-0.6 \% 0
$$


where $0.94 \%$ is the vital effect of $G$. ruber $r^{55}$ and $1 \%$ is the carbon isotope fractionation from DIC to carbonate $^{56}$ and $0.6 \%$ is the isotope difference between $50 \mathrm{~m}$ (mixed layer) and $150 \mathrm{~m}$ water (Supplementary Figure S10) in the modern West Pacific Warm Pool. This gradient would be larger when the ocean productivity enhanced causing a low estimation during the bloom period (the real value could be more positive than our estimation).

\section{Statistics strategies}

The coccolithophore productivity records employed in this study are derived by different proxies, including F. profunda percentage (Fp\%), coccolith abundance and coccolith accumulate. The correlation among these three proxies are quite significant (Supplementary Fig. S4) suggesting they can be compared with each other. However, these records have different sampling resolutions, magnitudes and units. For data from a same proxy and region, we normalized the $\log (N A b), \log (N A R)$ or (1-Fp\%) into a range of $0-1$ generating regional stacks. After that, all records, both single site data and regional stacks, were interpolated into $1 \mathrm{kyr}$ resolution and the cross-correlation analyses were performed between eccentricity orbital parameters by the Matlab function 'crosscorr'. The crosscorrelation analyses were only carried out for the 0-600 ka records assuming another coccolithophore bloom event happened around 700-900 ka with another low eccentricity period ${ }^{3}$. Since we assumed that the high coccolithophore productivity had relationships with low eccentricity, the lag with lowest correlation coefficient were chosen as the lag between the eccentricity and local coccolithophore productivity. If the lag or lead between productivity peak and eccentricity minimum was larger than $100 \mathrm{kyr}$, we think the high coccolithophore productivity had little correlation with low eccentricity. The high productivity period of diatom is defined as the periods when the productivity is higher than mean value plus 2 standard deviation in a window of $200 \mathrm{kyr}$. The window length and threshold value play minor roles in detecting the productivity peaks (Supplementary S3).

\section{Data availability}

All data generated during this study supporting its findings are supplied in supplementary data files.

\section{Reference}

1 Pälike, H. et al. The heartbeat of the Oligocene climate system. Science 314, 1894-1898 (2006).

2 Ridgwell, A. \& Zeebe, R. The role of the global carbonate cycle in the regulation and evolution of the Earth system. Earth and Planetary Science Letters 234, 299-315, doi:10.1016/j.epsl.2005.03.006 (2005).

3 Rickaby, R. et al. Coccolith chemistry reveals secular variations in the global ocean carbon cycle? Earth and Planetary Science Letters 253, 83-95 (2007).

4 Bown, P. Calcareous nannofossil biostratigraphy. (Chapman and Hall; Kluwer Academic, 1998). 
4445 Bendif, E. M. et al. Repeated species radiations in the recent evolution of the key marine

$445 \quad$ phytoplankton lineage Gephyrocapsa. Nat Commun 10, 4234, doi:10.1038/s41467-019-

$446 \quad$ 12169-7 (2019).

4476 Barker, S. et al. Globally increased pelagic carbonate production during the Mid-Brunhes

448 dissolution interval and the CO2 paradox of MIS 11. Quaternary Science Reviews 25, 3278-

$449 \quad 3293$, doi:10.1016/j.quascirev.2006.07.018 (2006).

4507 Kender, S. et al. Mid Pleistocene foraminiferal mass extinction coupled with phytoplankton

451 evolution. Nature Communications 7, 11970, doi:10.1038/ncomms11970

http://www.nature.com/articles/ncomms11970\#supplementary-information (2016).

4538 Russon, T., Paillard, D. \& Elliot, M. Potiential origins of 400-500 kyr periodicities in the ocean

454

455

456

457

458

459

460

461

462

463

464

465

466

467

468

469

470

471

472

473

474

475

476

477

478

479

480

481

482

483

484

485

486

487

488

489

490

491

492

493

494 carbon cycle: a box model approach. Global and Planetary Change 24, doi:10.1029/2009GB003586 (2010).

9 Beaufort, L. et al. Insolation cycles as a major control of equatorial Indian Ocean primary production. Science 278, 1451-1454 (1997).

10 McClelland, H. L., Bruggeman, J., Hermoso, M. \& Rickaby, R. E. The origin of carbon isotope vital effects in coccolith calcite. Nat Commun 8, 14511, doi:10.1038/ncomms14511 (2017).

11 Flores, J.-A., Filippelli, G. M., Sierro, F. J. \& Latimer, J. The “White Ocean” hypothesis: a late pleistocene southern ocean governed by coccolithophores and driven by phosphorus. Frontiers in microbiology 3 (2012).

12 López-Otálvaro, G.-E., Flores, J.-A., Sierro, F. J. \& Cacho, I. Variations in coccolithophorid production in the Eastern Equatorial Pacific at ODP Site 1240 over the last seven glacialinterglacial cycles. Marine Micropaleontology 69, 52-69 (2008).

13 Álvarez, M. C., Flores, J. A., Sierro, F. J. \& Molina-Cruz, A. Long-term upwelling evolution in tropical and equatorial Pacific during the last $800 \mathrm{kyr}$ as revealed by coccolithophore assemblages. Geobios 43, 123-130 (2010).

14 Marino, M. et al. Coccolithophores as proxy of seawater changes at orbital-to-millennial scale during middle Pleistocene Marine Isotope Stages 14-9 in North Atlantic core MD012446. Paleoceanography 29, 518-532 (2014).

15 Maiorano, P. et al. Coccolithophore variability from the Shackleton Site (IODP Site U1385) through MIS 16-10. Global and Planetary Change 133, 35-48 (2015).

16 Bordiga, M. et al. Calcareous plankton and geochemistry from the ODP site 1209B in the NW Pacific Ocean (Shatsky Rise): new data to interpret calcite dissolution and paleoproductivity changes of the last 450ka. Palaeogeography, Palaeoclimatology, Palaeoecology 371, 93-108 (2013).

17 Garcia, H. E. et al. World ocean atlas 2013. Volume 4, Dissolved inorganic nutrients (phosphate, nitrate, silicate). (2013).

18 Beaufort, L., Probert, I. \& Buchet, N. Effects of acidification and primary production on coccolith weight: Implications for carbonate transfer from the surface to the deep ocean. Geochemistry, Geophysics, Geosystems 8 (2007).

19 Dittert, N. et al. in Use of proxies in paleoceanography 255-284 (Springer, 1999).

20 Rea, D. K. \& Lyle, M. W. Paleogene calcite compensation depth in the eastern subtropical Pacific: Answers and questions. Paleoceanography 20, n/a-n/a, doi:10.1029/2004pa001064 (2005).

21 Holtz, L.-M., Wolf-Gladrow, D. \& Thoms, S. Stable carbon isotope signals in particulate organic and inorganic carbon of coccolithophores-A numerical model study for Emiliania huxleyi. Journal of Theoretical Biology 420, 117-127 (2017).

22 Kerr, J., Rickaby, R., Yu, J., Elderfield, H. \& Sadekov, A. Y. The effect of ocean alkalinity and carbon transfer on deep-sea carbonate ion concentration during the past five glacial cycles. Earth and Planetary Science Letters 471, 42-53, doi:10.1016/j.epsl.2017.04.042 (2017).

23 Qin, B., Li, T., Xiong, Z., Algeo, T. J. \& Jia, Q. Deep-Water Carbonate Ion Concentrations in the Western Tropical Pacific Since the Mid-Pleistocene: A Major Perturbation During the Mid- 
Brunhes. Journal of Geophysical Research: Oceans 123, 6876-6892, doi:10.1029/2018jc014084 (2018).

24 Jin, H., Jian, Z., Cheng, X. \& Guo, J. Early Pleistocene formation of the asymmetric east-west pattern of upper water structure in the equatorial Pacific Ocean. Chinese Science Bulletin 56, 2251-2257 (2011).

25 Shimada, C., Sato, T., Toyoshima, S., Yamasaki, M. \& Tanimura, Y. Paleoecological significance of laminated diatomaceous oozes during the middle-to-late Pleistocene, North Atlantic Ocean (IODP Site U1304). Marine Micropaleontology 69, 139-150 (2008).

26 Xuan, C., Channell, J. E. T. \& Hodell, D. A. Quaternary magnetic and oxygen isotope stratigraphy in diatom-rich sediments of the southern Gardar Drift (IODP Site U1304, North Atlantic). Quaternary Science Reviews 142, 74-89, doi:10.1016/j.quascirev.2016.04.010 (2016).

27 Diekmann, B. \& Kuhn, G. Sedimentary record of the mid-Pleistocene climate transition in the southeastern South Atlantic (ODP Site 1090). Palaeogeography, Palaeoclimatology, Palaeoecology 182, 241-258 (2002).

28 Kemp, A. E. S., Grigorov, I., Pearce, R. B. \& Naveira Garabato, A. C. Migration of the Antarctic Polar Front through the mid-Pleistocene transition: evidence and climatic implications. Quaternary Science Reviews 29, 1993-2009, doi:10.1016/j.quascirev.2010.04.027 (2010).

29 Martínez-Garcia, A. et al. Southern Ocean dust-climate coupling over the past four million years. Nature 476, 312-315 (2011).

30 Wolff, E. W. et al. Southern Ocean sea-ice extent, productivity and iron flux over the past eight glacial cycles. Nature 440, 491 (2006).

31 Naafs, B. D. A. et al. Strengthening of North American dust sources during the late Pliocene (2.7 Ma). Earth and Planetary Science Letters 317, 8-19 (2012).

32 Hillenbrand, C. D., Kuhn, G. \& Frederichs, T. Record of a Mid-Pleistocene depositional anomaly in West Antarctic continental margin sediments: an indicator for ice-sheet collapse? Quaternary Science Reviews 28, 1147-1159, doi:10.1016/j.quascirev.2008.12.010 (2009).

33 Ragueneau, O. et al. A review of the Si cycle in the modern ocean: Recent progress and missing gaps in the application of biogenic opal as a paleoproductivity proxy. Global and Planetary Change 26, 317-365 (2000).

34 Sarmiento, J. á., Gruber, N., Brzezinski, M. \& Dunne, J. High-latitude controls of thermocline nutrients and low latitude biological productivity. Nature 427, 56 (2004).

35 Balch, W. M. et al. The contribution of coccolithophores to the optical and inorganic carbon budgets during the Southern Ocean Gas Exchange Experiment: New evidence in support of the "Great Calcite Belt" hypothesis. Journal of Geophysical Research 116, doi:10.1029/2011jc006941 (2011).

36 Filippelli, G. M. The Global Phosphorus Cycle: Past, Present, and Future. Elements 4, 89-95, doi:10.2113/gselements.4.2.89 (2008).

37 Cheng, H. et al. The Asian monsoon over the past 640,000 years and ice age terminations. nature 534, 640 (2016).

38 Tian, J., Zhao, Q., Wang, P., Li, Q. \& Cheng, X. Astronomically modulated Neogene sediment records from the South China Sea. Paleoceanography 23 (2008).

39 Zhang, Y. G., Ji, J., Balsam, W. L., Liu, L. \& Chen, J. High resolution hematite and goethite records from ODP 1143 , South China Sea: co-evolution of monsoonal precipitation and EI Niño over the past 600,000 years. Earth and Planetary Science Letters 264, 136-150 (2007).

40 Wang, R. \& Li, J. Quaternary high-resolution opal record and its paleoproductivity implication at ODP Site 1143, southern South China Sea. Chinese Science Bulletin 48, 363-367 (2003).

41 Wang, P. et al. Long-term cycles in the carbon reservoir of the Quaternary ocean: a perspective from the South China Sea. National Science Review, nwt028 (2013).

42 Hoogakker, B. A. A., Rohling, E. J., Palmer, M. R., Tyrrell, T. \& Rothwell, R. G. Underlying causes for long-term global ocean $\delta 13 \mathrm{C}$ fluctuations over the last $1.20 \mathrm{Myr}$. Earth and Planetary Science Letters 248, 15-29, doi:http://dx.doi.org/10.1016/j.epsl.2006.05.007 (2006). 
43 Uemura, R. et al. Asynchrony between Antarctic temperature and $\mathrm{CO} 2$ associated with obliquity over the past 720,000 years. Nat Commun 9, 961, doi:10.1038/s41467-018-03328-3 (2018).

44 Krumhardt, K. M., Long, M. C., Lindsay, K. \& Levy, M. N. Southern Ocean calcification controls the global distribution of alkalinity. Global Biogeochemical Cycles, e2020GB006727 (2020).

$45 \mathrm{Wu}, \mathrm{H}$. et al. Time-calibrated Milankovitch cycles for the late Permian. Nature communications 4, ncomms3452 (2013).

46 Valero, L., Garcés, M., Cabrera, L., Costa, E. \& Sáez, A. 20 Myr of eccentricity paced lacustrine cycles in the Cenozoic Ebro Basin. Earth and Planetary Science Letters 408, 183-193, doi:10.1016/j.epsl.2014.10.007 (2014).

47 De Vleeschouwer, D. et al. High-latitude biomes and rock weathering mediate climate-carbon cycle feedbacks on eccentricity timescales. Nat Commun 11, 5013, doi:10.1038/s41467-02018733-w (2020).

48 Wang, P., Tian, J., Cheng, X., Liu, C. \& Xu, J. Carbon reservoir changes preceded major icesheet expansion at the mid-Brunhes event. Geology 31, 239-242 (2003).

49 Bordiga, M., Bartol, M. \& Henderiks, J. Absolute nannofossil abundance estimates: Quantifying the pros and cons of different techniques. Revue de micropaléontologie 58,155 165, doi:10.1016/j.revmic.2015.05.002 (2015).

50 González-Lemos, S., Guitián, J., Fuertes, M.-Á., Flores, J.-A. \& Stoll, H. M. An empirical method for absolute calibration of coccolith thickness. Biogeosciences Discussions, 1-20, doi:10.5194/bg-2017-249 (2017).

51 Fuertes, M.-Á., Flores, J.-A. \& Sierro, F. J. The use of circularly polarized light for biometry, identification and estimation of mass of coccoliths. Marine Micropaleontology 113, 44-55 (2014).

52 Zhang, H., Liu, C., Mejia, L. M. \& Stoll, H. Accelerate coccolith size separation via repeated centrifugation. Biogeosciences Discussions, 1-18 (2020).

53 Stoll, H. M. \& Ziveri, P. Separation of monospecific and restricted coccolith assemblages from sediments using differential settling velocity. Marine Micropaleontology 46, 209-221, doi:10.1016/S0377-8398(02)00040-3 (2002).

54 Zhang, H., Stoll, H., Bolton, C., Jin, X. \& Liu, C. Technical note: A refinement of coccolith separation methods: measuring the sinking characteristics of coccoliths. Biogeosciences 15, 4759-4775, doi:10.5194/bg-15-4759-2018 (2018).

55 Spero, H. J., Mielke, K. M., Kalve, E. M., Lea, D. W. \& Pak, D. K. Multispecies approach to reconstructing eastern equatorial Pacific thermocline hydrography during the past $360 \mathrm{kyr}$. Paleoceanography 18 (2003).

56 Zeebe, R. E. \& Wolf-Gladrow, D. CO2 in seawater: equilibrium, kinetics, isotopes. (Gulf Professional Publishing, 2001).

\section{Acknowledgement}

This work was funded by National Science Foundation of China (41930536, to 408 C.L.) ETH core funding (to H.M.S), and Chinese Scholarship Council (CSC) scholarship to H.Z. We thank the Integrated Ocean Drilling Program (IODP) and Zhinmin Jian for providing the samples. We also thank Madalina Jaggi's help in carbon isotope analyses.

\section{Competing interests}

The authors declare no competing interests.

\section{Author contributions}

H.Z., C.L and H.M.S designed and developed this study. I.H. provided support in data analyses and L.M.M helped in coccolith separation. H.Z, and H.M.S wrote the manuscript with valuable contributions from all other authors. 

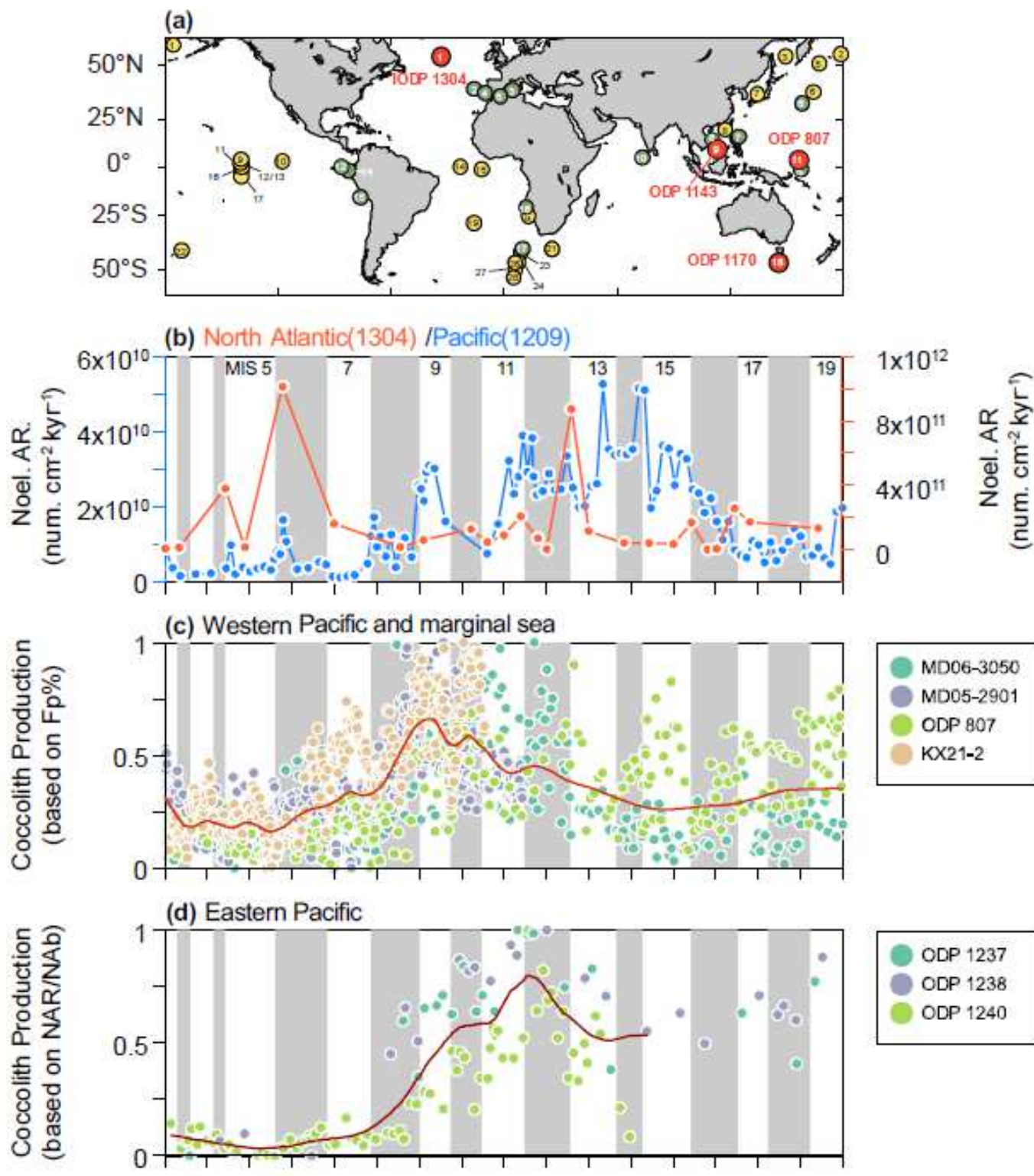

(e) Southern Ocean ( 1170/1089)

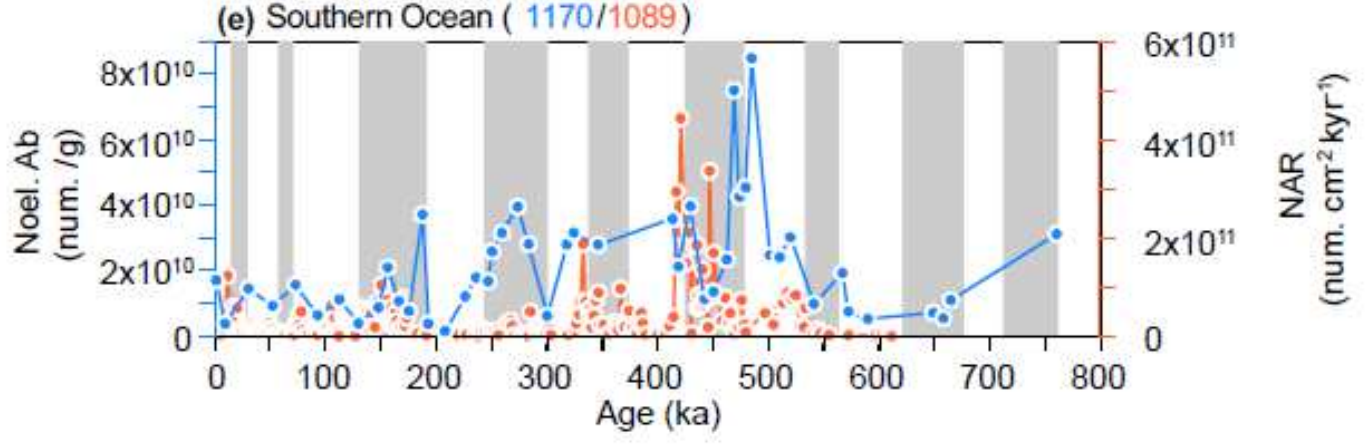

\section{Figure 1}

Sites map and coccolithophore and diatom productivity in the last $0.8 \mathrm{Myr}$. (a) The sample map: the red dots are new coccolithophore productivity provided in this study, the green ones are published coccolithophore productivity and the yellow ones are diatom productivity cited in this work. The numbers 
of coccolithophore and diatom productivity records are in Supplementary Tables S1 and S2, respectively. (b) The coccolithophore productivity in the North Atlantic (orange, IODP U1304) and Pacific (blue, ODP 1209)16. (c) The normalized coccolithophore productivity stack (Fp\%) from the tropical West Pacific and marginal sea (dots) and the red curve is loess smooth of stack. (d) The normalized coccolithophore productivity stack in the Eastern Pacific upwelling (dots) and the red curve is loess smooth of productivity stack. (e) Coccolithophore productivity in the Southern Ocean (orange ODP 1089 and blue ODP 1170). Note: The designations employed and the presentation of the material on this map do not imply the expression of any opinion whatsoever on the part of Research Square concerning the legal status of any country, territory, city or area or of its authorities, or concerning the delimitation of its frontiers or boundaries. This map has been provided by the authors.

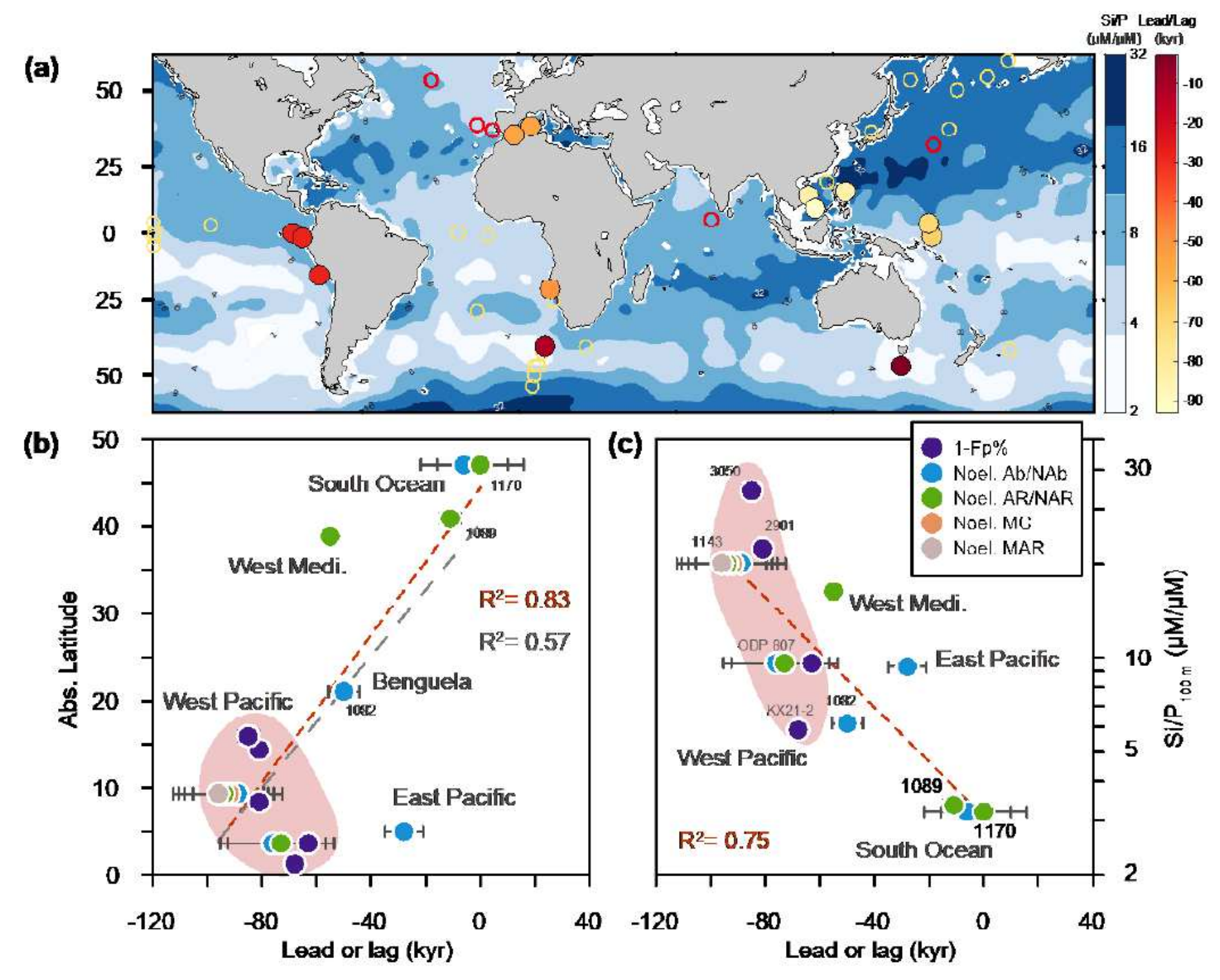

\section{Figure 2}

Coccolithophore bloom timing vs site location and nutrient ratio. (a) Coccolithophore bloom peak timing (relative to eccentricity minimum) against the core latitude and $\mathrm{Si} / \mathrm{P}$ ratio in the modern location of each core. Other diatom (yellow) or coccolithophore (red) productivity records cited in this work are plotted as 
circles. (b) The timing of coccolithophore bloom (relative to eccentricity minimum) against absolute latitude of cores. The red dash line represents the linear regression of data without Western Mediterranean and Eastern Pacific stacks ( $R 2=0.83$ and $p$-value $<<0.001)$ and the gray dash line is the regression of all data $(R 2=0.57$ and $p$-value $<<0.001)$. A negative $x$-axis value represents the peak of coccolithophore productivity happened late than the eccentricity minimum. (c) Timing of coccolithophore bloom (relative to eccentricity minimum) against Si/P ratio in $100 \mathrm{~m}$ depth (from World Ocean Atlas17). The red dash line is the linear regression of the lead-lag result to nutrient ratio $(R 2=0.75$ and $p-$ value $<<0.001$ ). The shaded areas in (b) and (c) heighten results from Western Pacific. Note: The designations employed and the presentation of the material on this map do not imply the expression of any opinion whatsoever on the part of Research Square concerning the legal status of any country, territory, city or area or of its authorities, or concerning the delimitation of its frontiers or boundaries. This map has been provided by the authors. 


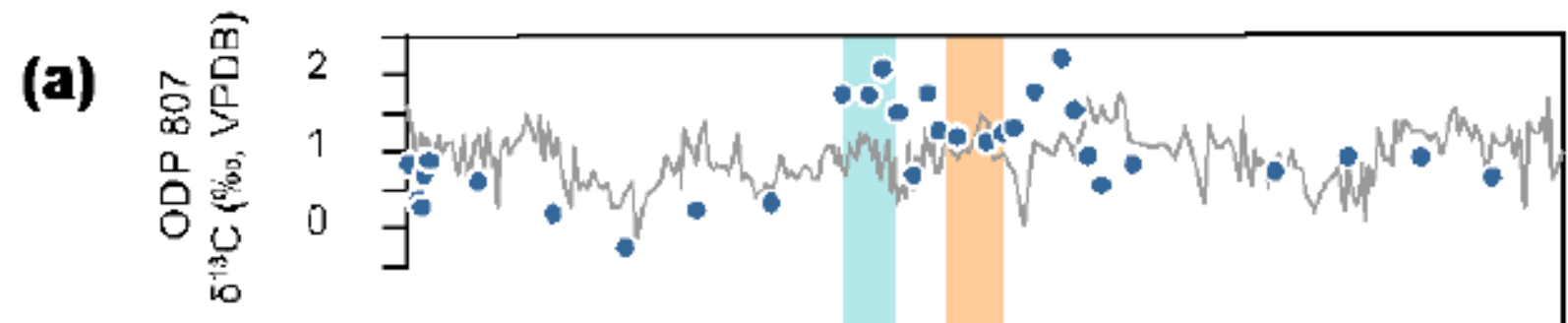

(b)

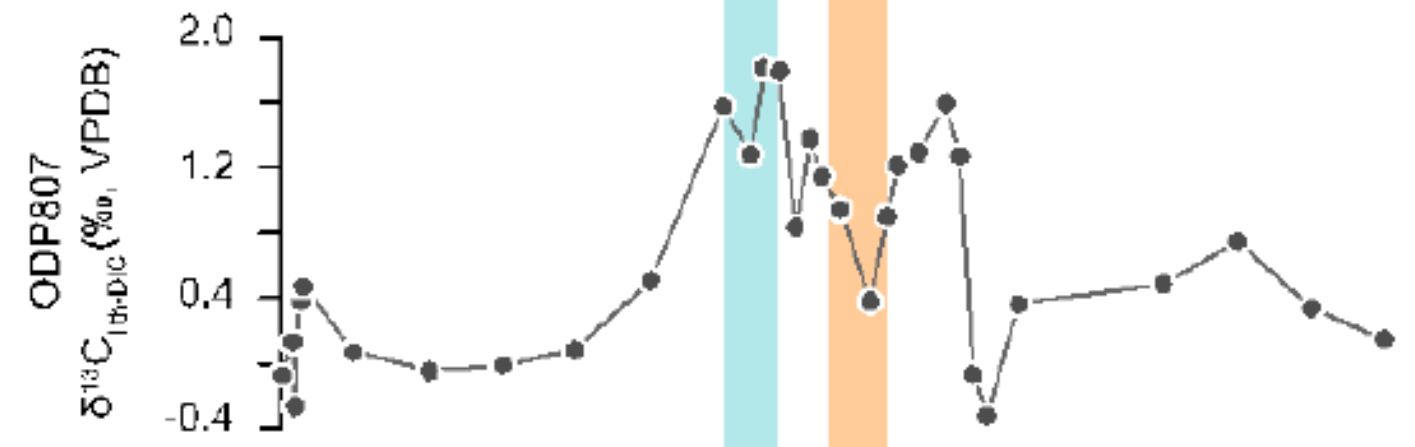

(c)
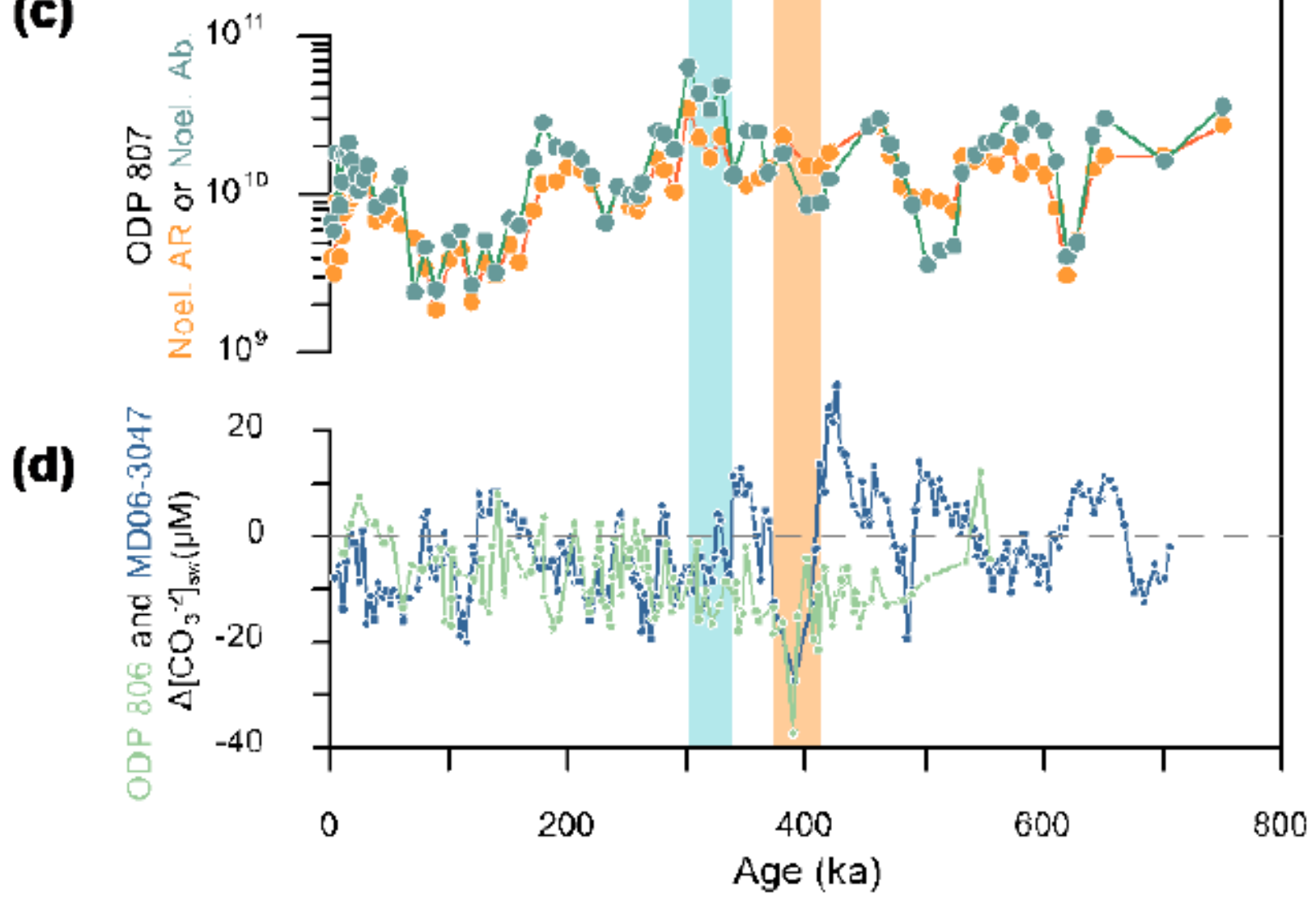

Figure 3

Coccolithophore productivity and dissolution records from the Western Pacific: (a) Coccolith (blue dots) and foraminifera (grey line, G. ruber)24 carbon isotope in site ODP 807; (b) Calculated coccolith carbon isotope vital effect in site ODP 807, which is higher when the coccolithophores grow faster and the CO2aq is lower assuming a fixed cellular PIC:POC ratio10. (c) Noelaerhabdaceae coccolith accumulation rate (Noel. AR, num. cm-2 kyr-1) and abundance (Noel. Ab with a unit of num. g-1) in the core ODP 807; 
(d) $\Delta$ [CO32] reconstruction in the Western Pacific: green dots are based on benthic foraminifera $\mathrm{B} / \mathrm{Ca}$ in site ODP 80622 and blue dots are based on G. ruber shell weight in the core of MD06-304723. The blue shading bar is the coccolithophore bloom peak detected in the Western Pacific and the orange one is the Mid-Brunhes dissolution event.

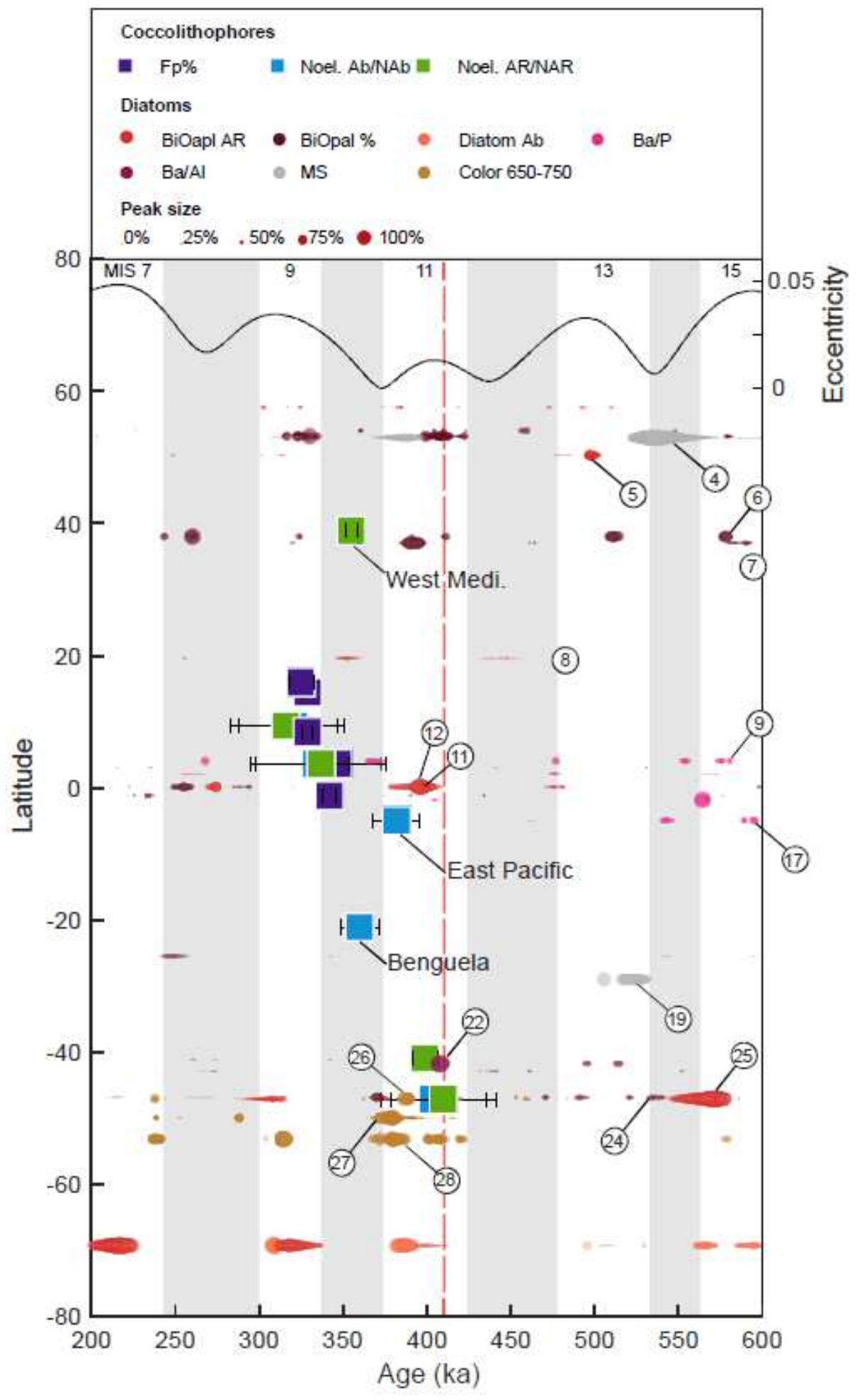

Figure 4 
The bloom pattern of coccolithophore and diatom from $600 \mathrm{ka}$ to $200 \mathrm{ka}$. The squares are the timing of coccolithophore bloom peaks and the different colors represent bloom peaks recorded by different proxies (see the legend). The numbers are diatom productivity records listed in Supplementary Table S2. The red dashed line represents the eccentricity minimum on the $405 \mathrm{kyr}-1$ band. The error bars are $95 \%$ confidence interval of coccolithophore bloom peak timing estimation base on cross-correlation. The dots are diatom high productivity periods and different colors represent results from each proxy (see the legend). Diatom productivity peaks represent periods when the productivity was larger than mean value+2 standard deviation in a $200 \mathrm{kyr}$ window (Method and Supplementary S3). A larger size of dots represents a more significant diatom productivity peak: $0 \%$ represents the smallest peak and $100 \%$ represent the largest productivity peak in the last $0.8 \mathrm{Myr}$. The results of Noel. MC and Noel. MAR from the core ODP 1143 are covered by Noel. Ab and Noel. AR squares and do not appear in the figure legend. 
(a)

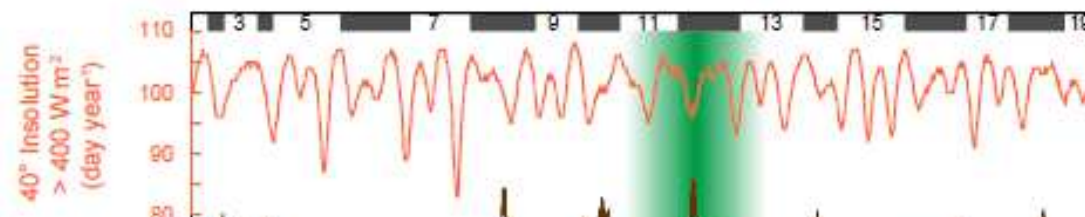

(b)

c) $\frac{8}{6} \frac{9}{0}$
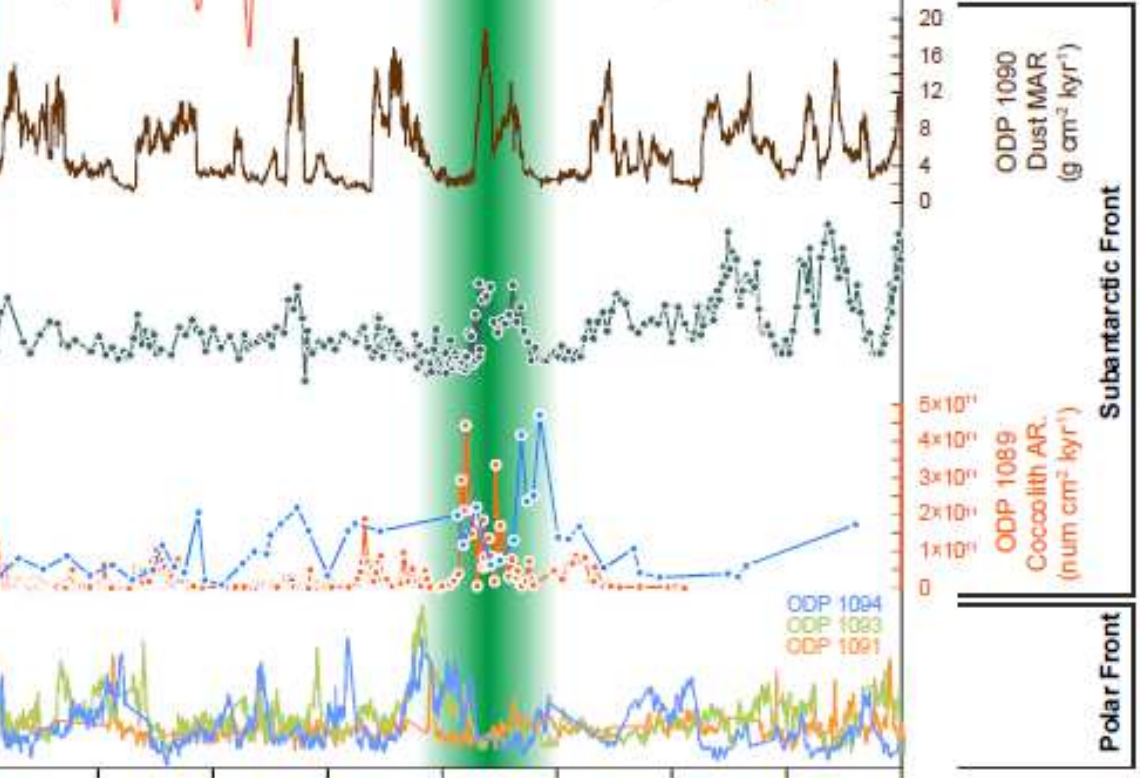

(f)

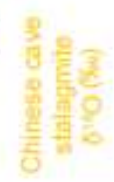

(g)

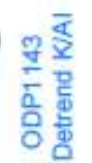

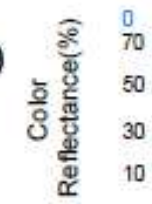

70
50
30
10
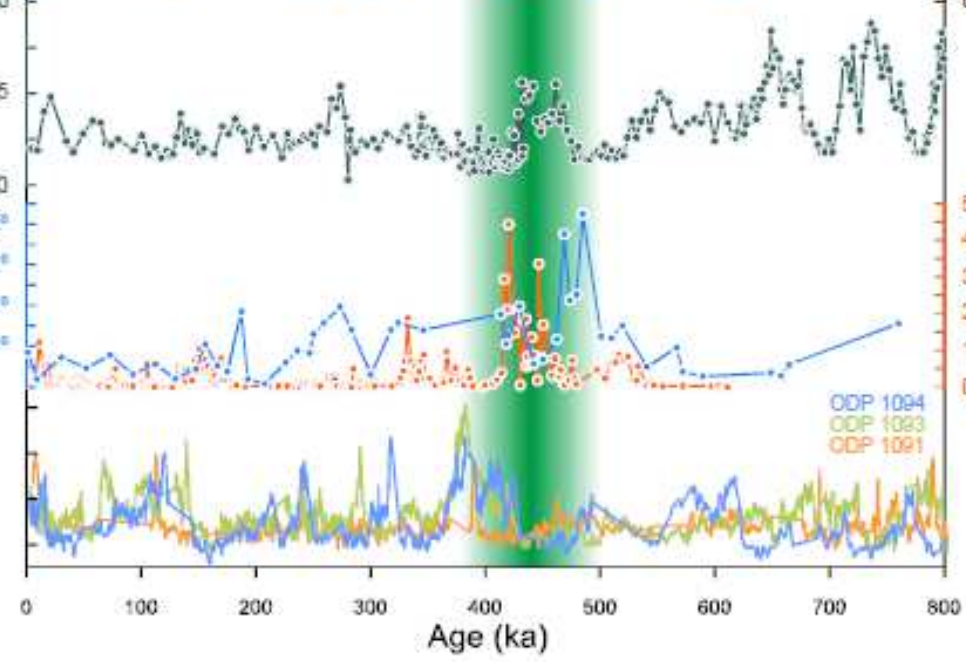

(d)

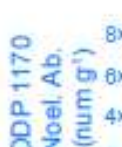

0
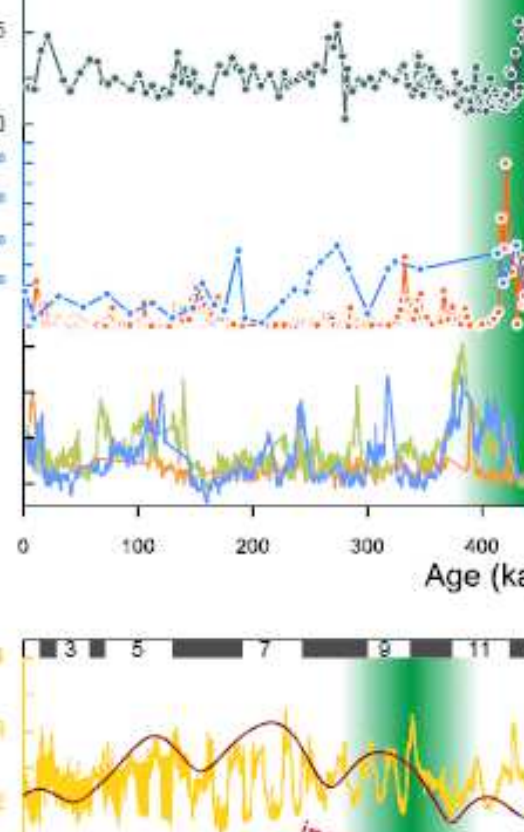

13

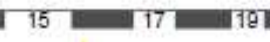

(h)

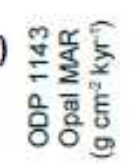

(i)
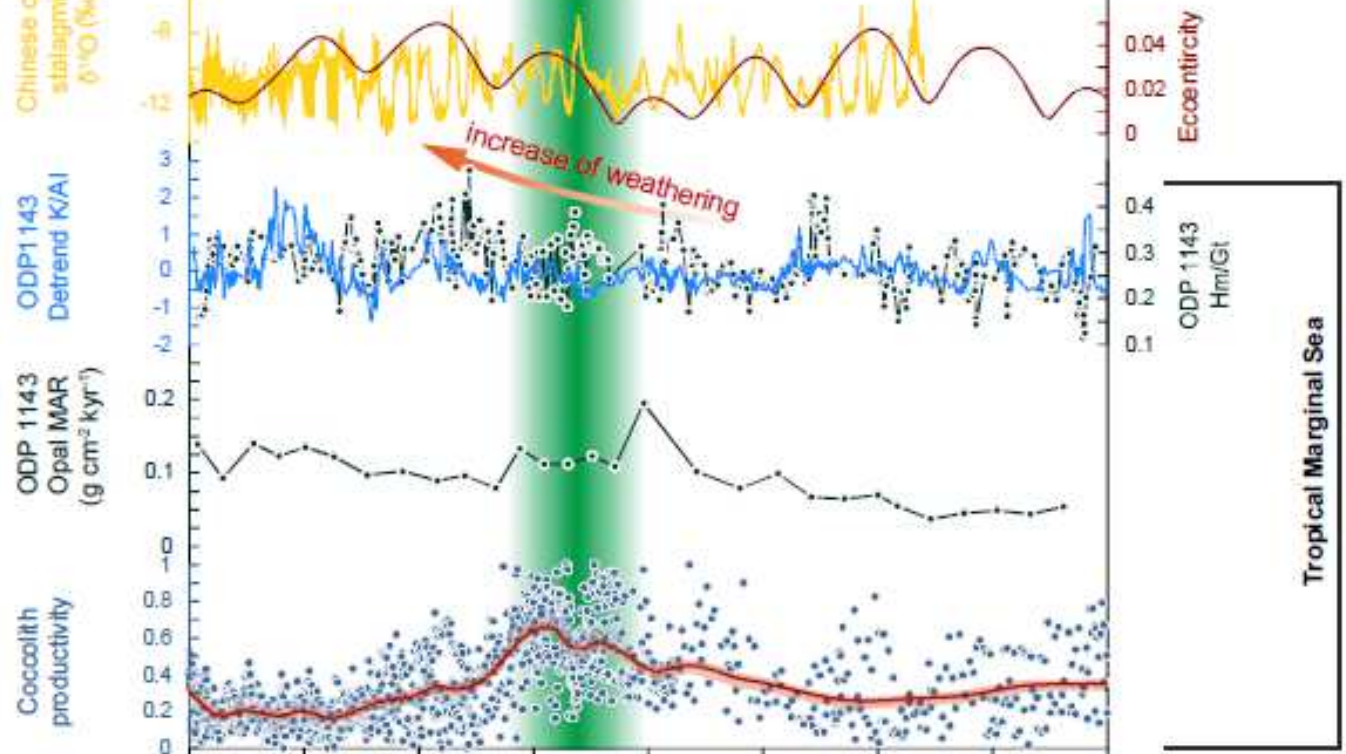

\section{Figure 5}

Trigger mechanisms of coccolithophore blooms in tropical seas and mid-high latitude ocean. The vertical green bars are coccolithophore bloom timing in the Southern Ocean (upper panel) and tropical West Pacific marginal seas (lower panel). (a) The coccolithophore growth season length defined a threshold of daily insolation $400 \mathrm{~W} \mathrm{~m}-2$ (growth durations defined by other thresholds are shown in Supplementary Fig. S13). (b) Dust accumulation rate in the site ODP 1090 Southern Ocean29. (c) Biogenic opal mass 
accumulation rate (MAR) as an indicator of diatom productivity from the core ODP 109027. (d) Coccolithophore productivity from the core ODP 1170 (blue) and the core 1089 (orange). (e) Color reflectance of sites ODP 1091, 1093 and 1094 on the Polar Front28. (f) Oxygen isotope of Chinese caves stalagmite (yellow) is an indicator of the Asian summer monsoon which is enveloped by eccentricity parameter (red) on $100 \mathrm{kyr}$ and $405 \mathrm{kyr}$ band37. (g) The weathering proxies from the core ODP $1143 \mathrm{in}$ the South China Sea38. The blue curve is the K/Al ratio and the dark green dots are the Hematite/Goethite ratio which are indicator of precipitation on the Indochina Peninsula39. Both of these records show a rapid increase of summer monsoon and fluvial flux from MIS 10 to MIS 9. (h) The opal MAR as a proxy for diatom productivity for ODP 114340. (i) The normalized coccolithophore productivity recorded by Fp\% in the Western Pacific (more details in the caption of Fig. 1c)

(a) MIS 13-MIS 11

Peak of Mid-Brunhes bloom at high latitude and upwelling

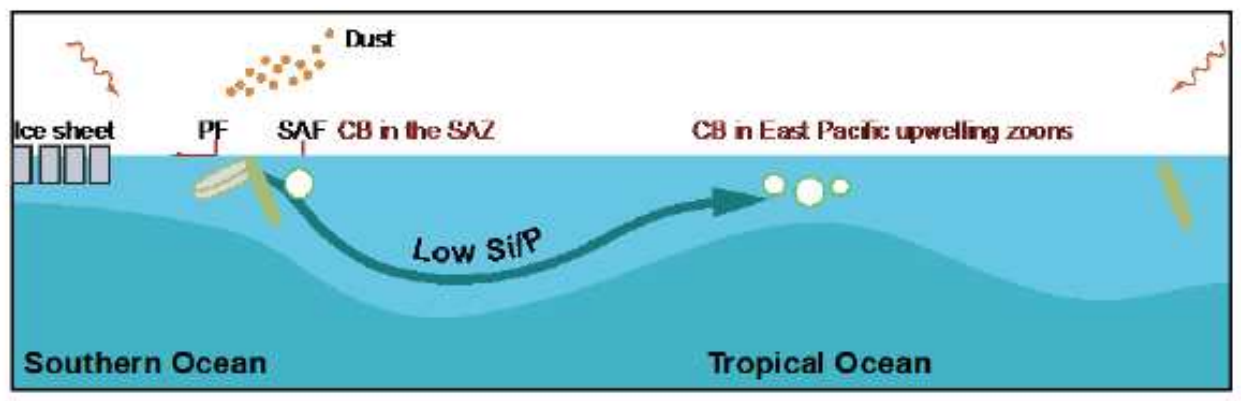

(b) MIS 11-MIS 9

Peak of Mid-Brunhes bloom at the Westem Pacific

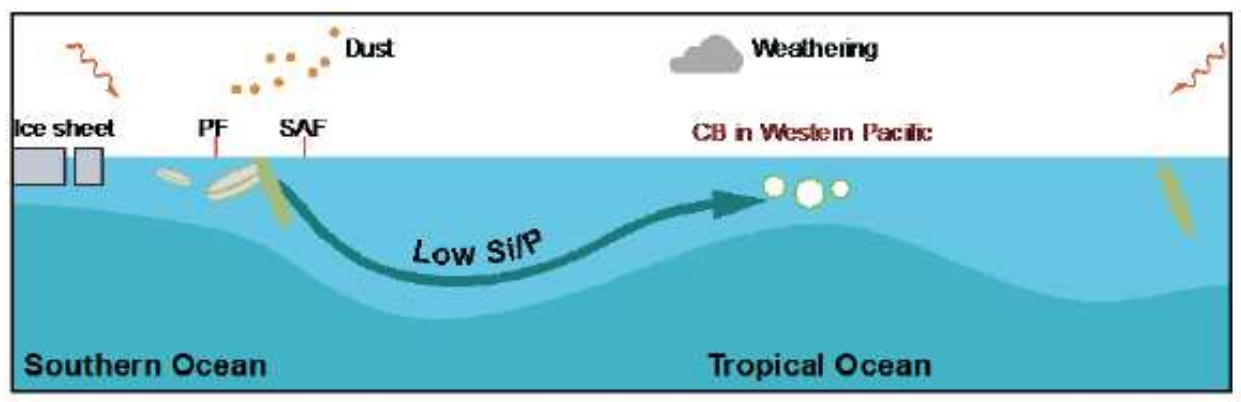

(c) MIS 9-MIS 7

High coccolithophore productivity period in the monsoon-driven upwelling zoon

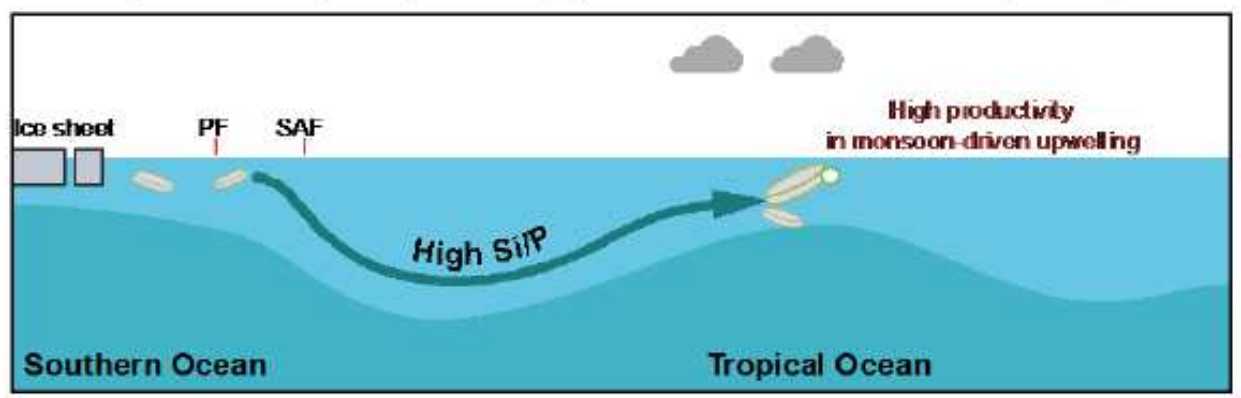

\section{South Ocean Mode \\ Peaks at MIS 13-MIS 11}

(d)

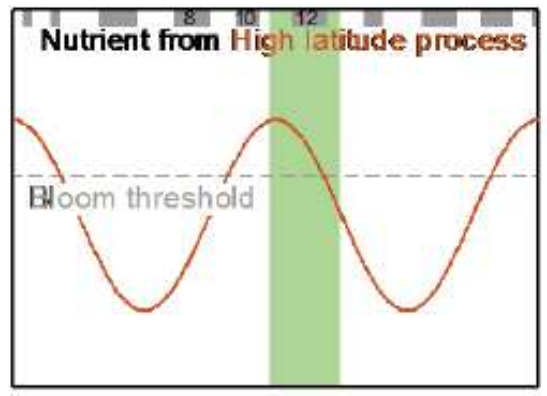

Western Pacific Mode

Peaks at MIS 11-MIS 9

(e)

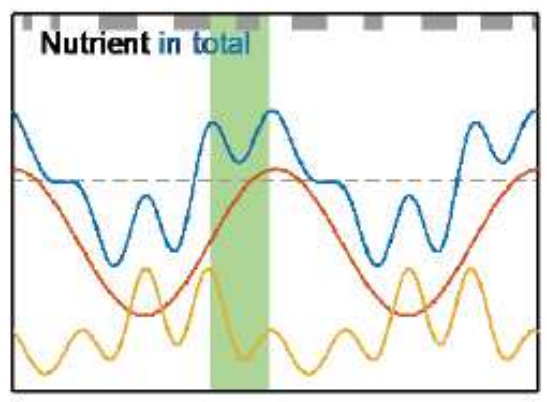

Tropical Indian Ocean Mode Peaks at MIS 9-MIS 7

(f)

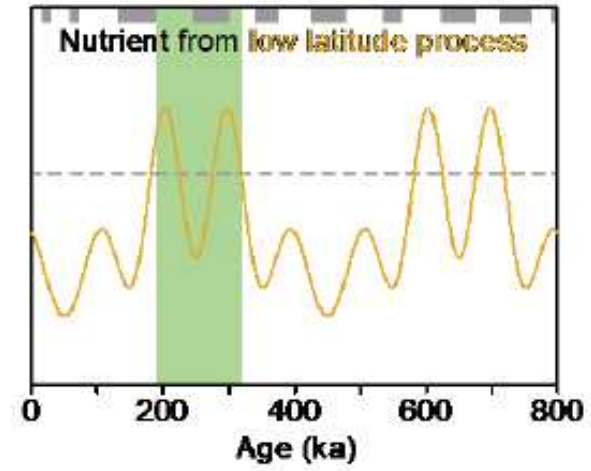


Three modes of coccolithophore bloom around Mid-Brunhes and afterwards. Trigger processes of coccolithophore bloom in three time slices: (a) Coccolithophore bloom pattern in the Southern Ocean and Eastern Pacific during MIS 13-12. (b) Coccolithophore bloom pattern in the Western Pacific during MIS 11-9. (c) Coccolithophore high productivity in monsoon driven upwelling region during MIS 8-7. (d-f) Nutrient source fueling coccolithophore productivity in three bloom modes. The nutrient sources from high latitude and low latitude processes were assumed to be driven only by orbital parameters (more details Supplementary S7). PF is the Polar Front, SAF is the Sub-Antarctic Front and CB is coccolithophore bloom.

\section{Supplementary Files}

This is a list of supplementary files associated with this preprint. Click to download.

- D1coccolithophoreproductivityrecords.xlsx

- D2diatomproductivityrecords.xlsx

- 02supportinginformation20210301.pdf 